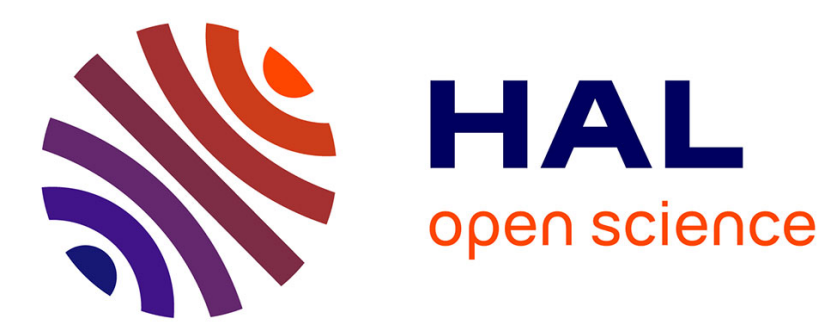

\title{
Entrepreneurial Progress: Climbing the Entrepreneurial Ladder in Europe and the US
}

Peter van Der Zwan, Ingrid Verheul, Roy Thurik, Isabel Grilo

\section{To cite this version:}

Peter van Der Zwan, Ingrid Verheul, Roy Thurik, Isabel Grilo. Entrepreneurial Progress: Climbing the Entrepreneurial Ladder in Europe and the US. Regional Studies, 2011, pp.1. 10.1080/00343404.2011.598504 . hal-00738298

\section{HAL Id: hal-00738298 https://hal.science/hal-00738298}

Submitted on 4 Oct 2012

HAL is a multi-disciplinary open access archive for the deposit and dissemination of scientific research documents, whether they are published or not. The documents may come from teaching and research institutions in France or abroad, or from public or private research centers.
L'archive ouverte pluridisciplinaire HAL, est destinée au dépôt et à la diffusion de documents scientifiques de niveau recherche, publiés ou non, émanant des établissements d'enseignement et de recherche français ou étrangers, des laboratoires publics ou privés. 


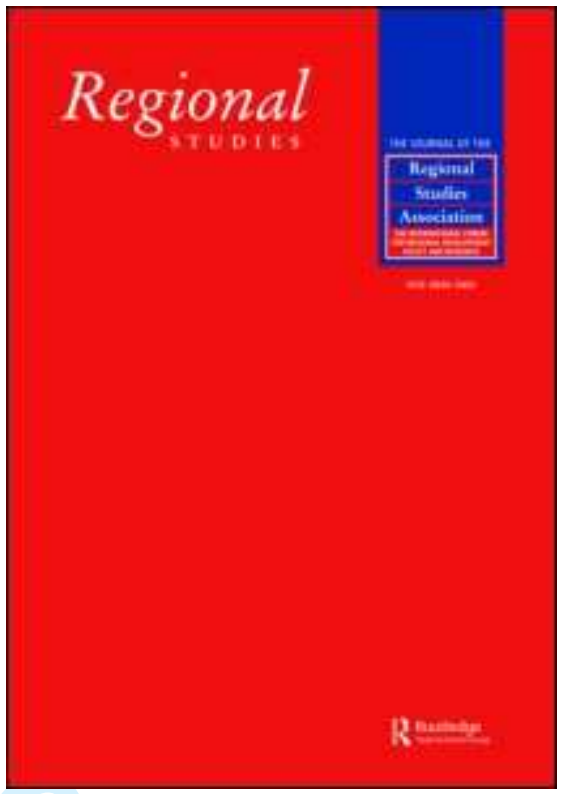

Entrepreneurial Progress:

Climbing the Entrepreneurial Ladder in Europe and the US

\begin{tabular}{|r|l|}
\hline Journal: & Regional Studies \\
\hline Manuscript ID: & CRES-2010-0231.R1 \\
\hline Manuscript Type: & Main Section \\
\hline JEL codes: & $\begin{array}{l}\text { J23 - Employment Determination; Job Creation; Labor Demand; } \\
\text { Self-Employment < J2 - Time Allocation, Work Behavior, and } \\
\text { Employment Determination/Creation < J - Labor and Demographic } \\
\text { Economics, L29 - Other < L2 - Firm Objectives, Organization, and } \\
\text { M1 - Business Administration < M - Business Administration and } \\
\text { Business Econ; Marketing; Accounting, R12 - Size and Spatial } \\
\text { Distributions of Regional Economic Activity < R1 - General Regional } \\
\text { Economics < R - Urban, Rural, and Regional Economics }\end{array}$ \\
\hline \hline Keywords: & $\begin{array}{l}\text { entrepreneurship, determinants, nascent entrepeneurship, } \\
\text { competitiveness, continuation ratio logit }\end{array}$ \\
\hline \hline
\end{tabular}

\section{SCHOLARONE" Manuscripts}




\title{
Entrepreneurial Progress: \\ Climbing the Entrepreneurial Ladder in Europe and the US
}

\author{
Peter van der Zwan ${ }^{\mathrm{a}, \mathrm{b}}$, Ingrid Verheul ${ }^{\mathrm{c}}$, Roy Thurik ${ }^{\mathrm{a}, \mathrm{d}, \mathrm{e}}$ and Isabel Grilo ${ }^{\mathrm{d}}$ \\ ${ }^{a}$ Centre for Advanced Small Business Economics, Erasmus School of Economics, Erasmus \\ University Rotterdam, P.O. Box 1738, 3000 DR Rotterdam, the Netherlands \\ vanderzwan@ese.eur.nl; thurik@ese.eur.nl \\ ${ }^{\mathrm{b}}$ EIM Business and Policy Research, P.O. Box 7001, 2701 AA Zoetermeer, the Netherlands \\ ${ }^{c}$ Department of Strategic Management and Entrepreneurship, Rotterdam School of Management, \\ Erasmus University Rotterdam, P.O. Box 1738, 3000 DR Rotterdam, the Netherlands \\ iverheul@rsm.nl \\ ${ }^{\mathrm{d}}$ DG Economic and Financial Affairs, European Commission, B-1049, Brussels, Belgium, and \\ CORE, Université catholique de Louvain \\ isabel.grilo@ec.europa.eu
}

(Received July 2010: in revised form June 2011) 


\begin{abstract}
This study investigates which countries have the highest potential to achieve entrepreneurial progress. This progress is defined as an entrepreneurial ladder with five successive steps: "never thought about starting a business", "thinking about it", "taking steps", "running a young business", and "running a mature business". The influences of individual-level and country-level variables on the progression through these stages are analyzed. Data from 27 European countries and the United States are used (2007 Flash Eurobarometer Survey on Entrepreneurship). Findings show that in the US, many people think about setting up a business, whereas Europeans are better at achieving higher levels of engagement. Country differences can be explained mainly by levels of risk tolerance and economic development. A country's level of administrative complexity does not play a role, but individual perceptions of this complexity are a hindering factor.
\end{abstract}

JEL-code: J23, L26, M13, R12

Keywords: entrepreneurship, determinants, nascent entrepreneurship, entrepreneurial progress, administrative complexities 


\section{Introduction}

The link between entrepreneurship and economic performance has been the subject of animated debates in academic and policy circles. Considering that new and small firms are the backbone of innovative activity, creating and maintaining an environment conducive to a dynamic business fabric with ample market opportunities will pay its dividends in terms of job creation and economic growth (CARREE and THURIK, 2010; AUDRETSCH and KEILBACH, 2004; BAPTISTA et al., 2008; EUROPEAN COMMISSION, 2008, ch.3). The potential to create, perceive, act upon, and commercialise these market opportunities can be seen as an important contribution of entrepreneurship to a region's level of competitiveness ${ }^{1}$. The role of entrepreneurship in enhancing the competitiveness of regions is emphasised by KITSON et al. (2004, p.997) who argue that “(...) competitive regions and cities are places where both companies and people want to locate and invest in". Hence, competitive regions tend to be characterised by a well-developed infrastructure that supports business activity. This is also underlined by the EUROPEAN COMMISSION (2009, p.17): "At the roots of competitiveness we find the institutional and microeconomic policy arrangements that create conditions under which businesses can merge and thrive and individual creativity and effort are rewarded". Each region has its own regulations and laws imposed by the government, as well as certain levels of competition and munificence of resources, that will determine the available market opportunities for entrepreneurs. More favourable regional conditions will enhance the ease with which (potential) firms come into existence, which in turn may positively affect a region's competitiveness. Alternatively, unfavourable economic circumstances, such as high unemployment rates, may push people to start up their own businesses (EVANS and LEIGHTON, 1990). However, empirical research is inconclusive about the direction of causality in the relationship between unemployment and the business ownership rate (REYNOLDS et al., 1994; THURIK et al., 2008; SANTARELLI et al., 2009).

Not only is the creation of new ventures important for regional performance, but so is their growth and survival. Entrepreneurship (i.e., starting up and managing a business) is often considered a process that consists of several stages (REYNOLDS, 1997; ROTEFOSS and KOLVEREID, 2005; 
GRILO and THURIK, 2008). This study defines entrepreneurial progress as an entrepreneurial ladder, where higher steps on this ladder refer to a higher level of entrepreneurial engagement (VAN DER ZWAN et al., 2010). Individuals can move through five sequential stages: "never thought about starting a business", "thinking about starting a business", "taking steps to start a business", "running a business for less than three years", and "running a business for more than three years" (GRILO and THURIK, 2008). Through climbing this proverbial ladder and stepping from one level to the next, individuals achieve entrepreneurial progress and contribute to the competitiveness of regions and nations.

This study empirically examines how and why entrepreneurial progress differs across 27 European countries and the United States. Specifically, it is investigated which countries' individuals have the highest likelihood of transitioning to higher levels of entrepreneurial engagement. The progress through the five stages of entrepreneurial engagement is related to several factors, including the level of economic development, a country's attitude towards risk and three country-level measures of business start-up impediments, including limited access to finance, administrative complexity and insufficient information. In addition, this study examines what the effects of individual-level factors (i.e., gender, age, education level, parental role models, risk attitude, perceived barriers to setting up a business, and residential area as a regional factor) are on the likelihood of advancement in the entrepreneurial process.

The contribution of this study to the existing knowledge base is threefold. First, the data set (the 2007 Flash Eurobarometer Survey on Entrepreneurship) allows for comparison of the conditions for entrepreneurial progress across 28 countries. For example, to what extent do individuals in the United States decide to become entrepreneurs and develop companies, compared to individuals in Europe? Which engagement levels are more difficult or easier to reach in the US, compared to other countries, and how can this be explained? We should mention here that our data were assembled in January 2007. This implies that our conclusions do not necessarily extend to periods of economic downturn that were experienced afterwards. For example, the relationship between individual-level factors such as perceived barriers to business start-up and entrepreneurial progress is likely to be influenced by the 
economic situation. Second, whereas most studies on the determinants of entrepreneurship focus on one level of analysis only (e.g., the individual or country level), the present multi-level analysis uses both individual- and country-level factors to explain entrepreneurial progress. In this way, the effects of individual perceptions and the objective state of environmental barriers are systematically disentangled. In fact, it has been argued that perceptions and the objective state of the entrepreneurial environment do not necessarily coincide (ARENIUS and MINNITI, 2005; VAN STEL and STUNNENBERG, 2006). Distinguishing between perceived and objective obstacles is also important from a policy perspective. Obviously, policy will have a different focus when obstacles are perceived than when they are real. Perception barriers can be dealt with by creating or improving awareness through providing (potential) entrepreneurs with more or better information, whereas the existence of a real obstacle requires efforts to reduce this barrier by directly intervening in the process. The third contribution is that, instead of explaining only one single stage of the entrepreneurial process (e.g., start-up) or the transition between two stages (e.g., from start-up to incumbent entrepreneurship), as is done in most studies, the focus here is on five different stages of the entrepreneurial process. The analysis takes into account the determinants of consideration for setting up a business (i.e., the likelihood of moving from "never considered" to "thinking"), the determinants of nascent entrepreneurship ("thinking" to "taking steps") and the success of these nascent activities ("taking steps" to "young business"), and the determinants of new firm development and survival ("young business" to "mature business"). The varying importance of the individual- and country-level factors across these transitions is assessed, which again may be vital for policy makers and important to take into account in follow-up studies.

The remainder of this study is structured as follows. After a detailed examination and discussion of the empirical literature, the data are introduced and discussed. Subsequently, the model is presented, followed by a discussion of the results. The paper ends with some concluding remarks, in which policy implications are addressed. 


\section{Determinants of Entrepreneurial Progress}

First, the importance of a range of important individual-level factors is discussed, including socio-demographic characteristics (gender, age, education level), role models (self-employed parents), personality aspects (risk tolerance and stigma of failure), and perceived barriers to entrepreneurship (administrative complexity, insufficient information on starting a business, lack of financial support). Subsequently, attention is paid to an individual's residential area, arguing that metropolitan and urban areas accommodate agglomeration effects that affect entrepreneurial activity. Finally, the focus is on differences in country characteristics that can affect the ease with which individuals advance in the entrepreneurial process.

\subsection{Individual-level Factors}

The empirical literature on individual-level determinants of entrepreneurship can be classified according to the different stages of entrepreneurial engagement. First, there are studies examining factors influencing the preference for self-employment vis-à-vis wage-employment (BLANCHFLOWER et al., 2001; GRILO and IRIGOYEN, 2006) and the intention to start a business (DAVIDSSON, 1995; KRUEGER et al., 2000; LEE et al., 2011; WILSON et al., 2007; ZHAO et al., 2010). Second, there is the research on the determinants of nascent entrepreneurship (DELMAR and DAVIDSSON, 2000; KIM et al., 2003; REYNOLDS, 1997) and the success of nascent activities, i.e., whether these activities lead to the start-up of a new venture (DAVIDSSON and HONIG, 2003; DIMOV, 2010; LICHTENSTEIN et al., 2007; PARKER and BELGHITAR, 2006; TOWNSEND et al., 2010; VAN GELDEREN et al., 2006, 2011). Subsequently, there are a large number of studies investigating the decision to become an entrepreneur, of which an overview is given in PARKER (2009, ch.4). Finally, there is an entire literature on the drivers of start-up or entrepreneurial success, measured, for example, in terms of survival or firm growth (BRÜDERL et al., 1992; COOPER et al., 1994; DAVIDSSON, 1991; VAN PRAAG, 2003; STAM et al., 2010; UNGER et al., 2011; ZHAO et al., 2010). For each individual factor that is taken into account in this study, the rationale behind, and empirical evidence of, the importance at the various levels of entrepreneurial engagement is elaborated 
on.

\section{Gender}

There are different perspectives on the existence of gender differences. According to the liberal feminist perspective, women and men behave differently because they are confronted with unequal access to resources and opportunities. The social feminist perspective, on the other hand, assumes that women and men are inherently different because of differences in early and ongoing socialization (FISCHER et al., 1993). In entrepreneurship research, evidence of gender differences is mixed. Nevertheless, gender has been found to influence entrepreneurial behaviour at different stages of the process. For example, women tend to have a lower preference for entrepreneurship (BLANCHFLOWER et al., 2001; GRILO and IRIGOYEN, 2006) and are more reluctant to start up a business (ALLEN et al., 2008; DAVIDSSON, 2006) than men. In terms of engagement in entrepreneurship there is evidence that women are less likely to run young or mature firms (LANGOWITZ and MINNITI, 2007; MINNITI, 2010; REYNOLDS et al., 2002; VERHEUL et al., 2011). Several scholars have argued that, when controlled for relevant factors, the "direct" effect of gender on new venture creation and performance is non-existent or limited (FAIRLIE and ROBB, 2009; PARKER and BELGITHAR, 2006; COLLINS-DODD et al., 2004; KALLEBERG and LEICHT, 1991; WATSON, 2002).

\section{Age}

A positive effect of age on self-employment may be expected for a variety of reasons. Older people may have accumulated more knowledge and financial capital, they have had more time than young people to build up a network, and they may decide to switch to self-employment to avoid compulsory retirement provisions (PARKER, 2009). On the other hand, older people may be more risk averse (MILLER, 1984), may attach less value to future earnings out of the firm, and are subject to increasing opportunity costs of self-employment because income from wage-employment increases with age (e.g., seniority) (LÉVESQUE and MINNITI, 2006). In line with these different theoretical arguments, empirical evidence of the relationship between age and entrepreneurship is mixed. The significance and direction of the relationship also depends upon the stage in the entrepreneurial 
process. For example, for entrepreneurial preferences a U-shaped relationship has been found (GRILO and THURIK, 2005; BLANCHFLOWER et al., 2001). Regarding nascent entrepreneurship, some scholars argue that there is a negative relationship with age (REYNOLDS, 1997; DELMAR and DAVIDSSON, 2000; DAVIDSSON and HONIG, 2003), whereas others find a positive or inverse Ushaped relationship (CROSA et al., 2002; KIM et al., 2003). For start-up success, several studies show that there is no significant relationship with age (DAVIDSSON and HONIG, 2003; PARKER and BELGHITAR, 2006; VAN GELDEREN et al., 2006). For actual involvement in self-employment there is evidence of a positive (GRILO and IRIGOYEN, 2006; COWLING, 2000) or an inverse Ushaped relationship with age (REES and SHAH, 1986; BORJAS and BRONARS, 1989; BEUGELSDIJK and NOORDERHAVEN, 2005; GEORGELLIS et al., 2005; BLANCHFLOWER and SHADFORTH, 2007). Finally, several studies find a positive relationship between age and firm survival (BATES, 1990; VAN PRAAG, 1996, 2003; TAYLOR, 1999; GIMENO et al., 1997).

\section{Education}

Education may stimulate opportunity recognition and improve the ability to successfully start and manage a new firm and grow an established business. Alternatively, higher educated people may have other (more lucrative) employment options that compel them to pursue a career in wageemployment. Empirical findings confirm this indeterminate effect of education level on advancement in the entrepreneurial process. Education level does not appear to have an effect on the preference for self-employment (BLANCHFLOWER et al., 2001; GRILO and THURIK, 2005; ROTEFOSS and KOLVEREID, 2005). For nascent entrepreneurship several studies report a positive relationship with education (DELMAR and DAVIDSSON, 2000; DAVIDSSON and HONIG, 2003; ROTEFOSS and KOLVEREID, 2005; ARENIUS And MINNITI, 2005), although REYNOLDS (1997) does not find a significant relationship. Results are mixed for the self-employment decision and firm success. For selfemployment, there is evidence of positive (BATES, 1995), negative (BURKE et al., 2002), nonlinear (REES and SHAH, 1986), and insignificant (VAN DER SLUIS et al., 2005) relationships. Similarly, for success, findings point at positive (COOPER et al., 1994; GIMENO et al., 1997; BOSMA et al., 2004; VAN DER SLUIS et al., 2007), negative (LUSSIER, 1995; BRÜDERL and 
PREISENDÖRFER, 1998) and insignificant (SCHUTJENS and WEVER, 2000) effects.

In addition to the level of education, the type of education may influence entrepreneurial activity. Specifically, education can stimulate individuals to develop their entrepreneurial skills and attitudes (KURATKO, 2005). ${ }^{2}$ Empirical evidence of the effects of entrepreneurship education on entrepreneurial involvement is scarce (GORMAN et al., 1997). Several empirical studies find that participation in entrepreneurship education increases intention to start a business (CLARK et al., 1984; PETERMAN and KENNEDY, 2003; KOLVEREID and MOEN, 1997) ${ }^{3}$, although OOSTERBEEK et al. (2007) report a negative effect. Unfortunately, existing studies do not provide insight into the quality of the firms started and run by individuals with entrepreneurship education. The present study investigates whether an entrepreneurial attitude, fostered by education, enhances entrepreneurial progress.

\section{Role models}

Role models, and in particular self-employed family members, appear important for predicting involvement in entrepreneurial activity. The opinion of significant others often plays a decisive role in individual decision making (AJZEN, 1991). Parents may not only shape the entrepreneurial preferences (BOYD and VOZIKIS, 1994) and intentions of their children (DAVIDSSON, 1995), but they may also provide financial support and advice in the period after start-up. Empirical evidence shows that parental role models are important for explaining entry into self-employment (DE WIT and VAN WINDEN, 1989; TAYLOR, 1996; MATTHEWS and MOSER, 1996; DUNN and HOLTZEAKIN, 2000; HOUT and ROSEN, 2000; GEORGELLIS et al., 2005; CALIENDO et al., 2009) and success (COOPER et al., 1994; GIMENO et al., 1997), although there is also evidence of less straightforward relationships, mainly at later stages of entrepreneurial engagement. Several studies find insignificant relationships between the availability of parental role models and firm success or survival (BATES, 1990; BRÜDERL et al., 1992; COOPER et al., 1994; GIMENO et al., 1997; TAYLOR, 1999).

\section{Risk tolerance and stigma of failure}


Entrepreneurs are often portrayed as risk-tolerant individuals (KIHLSTROM and LAFFONT, 1979). High failure rates of new ventures and high-income volatilities contribute to this "risky" image of entrepreneurship. Empirical evidence suggests that risk-tolerant people are more likely to have a preference for self-employment, vis-à-vis wage-employment, than risk-averse individuals (GRILO and THURIK, 2005; GRILO and IRIGOYEN, 2006). Positive effects of risk tolerance are also found for self-employment intentions (LÜTHJE and FRANKE, 2003; SEGAL et al., 2005) and the probability of being self-employed (CRAMER et al., 2002; CALIENDO et al., 2009). Nevertheless, studies by ROSEN and WILLEN (2002) and NORTON and MOORE (2006) conclude that risk attitude is not an important consideration in the decision to start a business. VAN GELDEREN et al. (2006) conclude that a higher perceived market risk implies a higher chance of failure of nascent activities. Finally, CALIENDO et al. (2010) investigate the relationship between risk attitudes and entrepreneurial survival and find that persons whose risk attitudes are in the medium range have higher chances of survival than those who have particularly low or high risk attitudes.

In addition to risk tolerance (i.e., whether the possibility of business failure deters entrance) a proxy is included for the extent to which an individual stigmatises failure. A tendency to accept failure may signal that an individual is willing to search for new possibilities and learn through experimentation, whereas an anti-failure attitude can obstruct entrepreneurial endeavours, as it makes individuals reluctant to experiment and does not allow them to learn from mistakes (SHEPHERD, 2003; POLITIS, 2005).

\section{Perceived barriers to entrepreneurship}

Perception variables are important factors in the explanation of potential entrepreneurship (KRUEGER and BRAZEAL, 1994), nascent entrepreneurship (ARENIUS and MINNITI, 2005), and young and established business ownership (KOELLINGER et al., 2007). Although specific regions may be more or less favourable for new venture creation and development, ultimately individuals make the decision to engage in entrepreneurial activity based on their perceptions of the environment. Hence, subjective perceptions of the (objective) environmental conditions are essential in explaining individual differences in start-up inclinations and higher levels of entrepreneurial engagement. This 
means that the objective and subjective measures of the entrepreneurial environment do not necessarily coincide (VAN STEL and STUNNENBERG, 2006).

The present study examines three perceived impediments to entrepreneurship: the perception of administrative complexity, lack of start-up information, and lack of financial support. Coping with administrative regulations is often cited as an important constraint to entrepreneurship. Initially, entrepreneurs have to cope with registration procedures, and in later stages, they are confronted with hiring and firing legislation. Several studies find that perceived administrative complexity has a negative impact on entrepreneurial preferences, intentions and behaviour (GRILO and IRIGOYEN, 2006; GRILO and THURIK, 2005, 2008; LÜTHJE and FRANKE, 2003; VAN STEL and STUNNENBERG, 2006).

Although access to financing has been reported as an important barrier for self-employment (EVANS and JOVANOVIC, 1989; EVANS and LEIGHTON, 1989; BLANCHFLOWER and OSWALD, 1998) and the performance of nascent entrepreneurs and start-ups (BRÜDERL et al., 1992; COOPER et al., 1994; CARTER et al., 1996; PARKER and BELGHITAR, 2006), evidence of the effect of an individual's perceived lack of finance is scarce. GRILO and IRIGOYEN (2006) find no significant effect of a perceived lack of financial support on the preference for, and involvement in, self-employment. LÜTHJE and FRANKE (2003) find that the belief that banks are reluctant to give credit to start-up companies negatively affects entrepreneurial intentions.

\subsection{Regional Factor: Urban versus Rural Areas}

Regional characteristics play an important role in explaining firm start-up (ARMINGTON and ACS, 2002; GUESNIER, 1994; JOHNSON and PARKER, 1996) and survival (FRITSCH et al., 2006; FALCK, 2007). Urban areas are often characterised by economies of specialization, many market opportunities, and access to a large pool of resources. In addition, the large concentration of entrepreneurs in these areas lowers the ambiguity attached to entrepreneurship (MINNITI, 2005). The availability of resources and social networks that provide access to these resources (Sørenson and SORENSON, 2003; STUART and SORENSON, 2003) makes it less likely that entrepreneurial intentions and efforts are constrained in urban areas. Based on MARSHALL (1920), ARMINGTON 
and ACS (2002) give three reasons for the existence of agglomeration effects in urban areas. First, firm birth rates in these areas are higher because of a pooled labour market. Second, the lower cost and greater variety of non-pecuniary transactions in such regions boosts start-up rates. Third, densely populated areas with a high level of business activity are characterised by positive effects of knowledge spill-over. ${ }^{4}$

The positive effect of knowledge spill-over on firm birth rates (ARMINGTON and ACS, 2002; ACS and ARMINGTON, 2004), firm growth (AUDRETSCH and DOHSE, 2007; RASPE and VAN OORT, 2008), and firm survival (ACS et al., 2007; RASPE and VAN OORT, 2008) has been widely investigated and supported. AUDRETSCH and DOHSE (2007) suggest that the agglomeration effect can be attributed to knowledge intensity rather than to population and industry intensity. ACS and ARMINGTON (2004) find that population growth, not size, has a positive relationship with birth rates. There is also evidence of negative agglomeration effects on firm survival (SORENSON and AUDIA, 2000). This might be due to the more fierce competition in urban areas (FRITSCH and MUELLER, 2008; VAN STEL and SUDDLE, 2008). STAM et al. (2010) find that, relative to rural areas, individuals in urban areas are less likely to give up their intentions and efforts to start their own businesses, but at the same time are more likely to fail than their rural counterparts.

In the Flash Eurobarometer Survey respondents report whether they live in a metropolitan, urban or rural area. As these are self-reports, interpretation differences may be present. For example, a region with a certain size or density may be assigned to different categories by individuals across countries. To lower the risk of bias, metropolitan and urban areas are combined into one variable. It is to be expected that the metropolitan/urban versus rural variable would show high correlation with other measures of agglomeration patterns (such as population density or city size) across countries. ${ }^{5}$

\subsection{Country-Level Factors}

In addition to individual and location factors, country-level factors play a role in explaining entrepreneurial engagement. There is evidence of cross-country and cross-regional variations in preferences for entrepreneurship (GRILO and IRIGOYEN, 2006; MASUDA, 2006), levels of nascent entrepreneurship (WENNEKERS et al., 2005; REYNOLDS et al., 2005) and established 
entrepreneurship (VAN STEL, 2005; BLANCHFLOWER, 2000). Empirical studies have explained this variation in terms of a wide range of factors, including economic, cultural, institutional and demographic factors (e.g., BLAU, 1987; CARREE et al., 2002; WENNEKERS et al., 2005; PARKER and ROBSON, 2004; NOORDERHAVEN et al., 2004; FREYTAG and THURIK, 2007; BOWEN and DE CLERCQ, 2008).

This study investigates country-level effects on the likelihood of belonging to, and switching between, different stages in the entrepreneurial process. The focus is on the role of a country's regulatory environment (in terms of administrative burden, information provision, and financial support), a country's attitude towards risk, the level of economic development, and competitiveness ${ }^{6}$. These are all important factors in the explanation of cross-country variations in entrepreneurship (VERHEUL et al., 2002).

Countries differ in the way they regulate and stimulate entry and firm development. Empirical evidence shows that the regulatory environment can have an important effect on entrepreneurial activity at the macro level. For example, KLAPPER et al. (2006) show that entry regulations are an important determinant of new firm entry and the growth of incumbent firms, in particular in sectors traditionally characterised by high entry. In addition, they find that firm entry is dependent on access to capital. More specifically, entry is higher in financially dependent industries when there is availability of both private (bank) credit and trade credit. Comparing the highly regulated economy of Spain with the less regulated British economy, CAPELLERAS et al. (2008) find that firms in Spain start larger, but that they grow slower. ${ }^{7}$ According to BAUMOL (1990), the degree of regulation does not influence the number of firms, but it does influence the distribution of registered and unregistered firms. VAN STEL et al. (2007) find that labour market regulations lead to lower rates of entrepreneurship, but that the impact of entry regulations is limited. That is, only the minimum capital required to register a new business has an effect, while the time, cost and number of procedures required to legally operate a firm appear insignificant in explaining rates of nascent and young business ownership.

An entrepreneurial culture is crucial for achieving entrepreneurial progress. There are several 
indicators of an entrepreneurial culture, including media attention for successful entrepreneurs who can serve as role models and respect for people who start up and run new businesses (REYNOLDS et al., 1999). Furthermore, country levels of individualism and uncertainty avoidance may affect start-up rates and levels of entrepreneurship. Countries with high levels of individualism often provide individuals with room to pursue the career of their choice, and value individual achievements of successful entrepreneurs. Countries characterised by high levels of uncertainty avoidance (or a riskaverse attitude) often have strict, formal rules and procedures, and residents are inclined to seek the security of wage-employment (HOFSTEDE, 1985). However, the relationship between culture and entrepreneurship at the country level does not always follow intuition. BAUM et al. (1993) find a negative impact of individualism on entrepreneurship, and WENNEKERS et al. (2007) show a positive relationship between Hofstede's Uncertainty Avoidance Index and business ownership. These counterintuitive findings may be explained in terms of dissatisfaction. For example, in countries with higher uncertainty avoidance, individuals may leave large organizations because they cannot satisfy their "entrepreneurial needs" (NOORDERHAVEN et al., 2004).

In addition to the regulatory and cultural environment, a country's economic environment is important in determining entrepreneurial engagement and progress. At the macro level, an important link is found between (nascent) entrepreneurship and the level of economic development. There is evidence of a U-shaped or L-shaped relationship between entrepreneurship and economic growth (CARREE et al., 2002; CARREE et al., 2007; WENNEKERS et al., 2010). The rationale behind the $\mathrm{U}$-shape is that a higher level of economic development is accompanied by rising real wages, thereby increasing the opportunity costs of entrepreneurship. After a certain level of economic development, technological development and the size of the service sector increase, while the employment share of manufacturing decreases. From this perspective it is important to distinguish between low- and highincome countries. In the present data set low-income countries are mainly transition economies that until recently were characterised by a centrally planned economy instead of a market economy. Business environments in transition economies are less favourable than in non-transition economies (SMALLBONE and WELTER, 2001; MUGLER, 2000). Still, there is some evidence that in transition 


\section{Data and Descriptive Statistics}

To investigate the ease with which entrepreneurs climb the entrepreneurial ladder, and to identify the factors that may facilitate or slow down their progress, the 2007 Flash Eurobarometer Survey on Entrepreneurship, No.192, of the European Commission is used. The survey consists of 20,674 observations for 25 Member States of the European Union as well as Norway, Iceland, and the United States. In January 2007, in each country randomised telephone interviews were conducted with respondents aged 15 years and over. ${ }^{8}$ Respondents were asked the following question: "Have you ever started a business or are you taking steps to start one?" Answer categories include:

(1) No, it never came to my mind ("never considered");

(2) No, but I am thinking about it ("thinking”);

(3) Yes, I am currently taking steps to start a new business ("taking steps");

(4) Yes, I have started or taken over a business in the last three years and it is still active (“young business");

(5) Yes, I started or took over a business more than three years ago and it is still active (“mature business").

The question contains three additional answer categories: ${ }^{9}$

(2a) No, I thought of it or had already taken steps to start a business but gave up ("gave 
up");

(5a) Yes, I once started a business, but currently am no longer an entrepreneur since the business has failed ("failure");

(5b) Yes, I once started a business, but currently I am no longer an entrepreneur since the business was sold, transferred or closed (“sell-off”).

The Flash Eurobarometer data emphasise the pre-start-up phase of a company. This pre-birth phase consists of three sub-stages ("never considered", "thinking", "taking steps"). The "taking steps" stage refers to nascent entrepreneurship. The firm birth itself takes place between the third ("taking steps") and the fourth stage ("young business"). The distinction between a young and a mature business is based on a period of 36 months. ${ }^{10}$ This period does not take into account the fact that firms in fast-growing industries probably climb the entrepreneurial ladder more rapidly than firms in less dynamic industries, where it may take longer to transform a young business into a mature one.

A description of the explanatory variables is given in Table 1. The individual-level variables include five variables for which the initial individual values have been subtracted from the calculated country averages for these variables. These variables are risk tolerance, stigma of failure, and the three perception variables (perceived administrative complexity, perceived lack of relevant information, perceived lack of finance). Individual deviations from the country averages (i.e., how much the perception of the individual respondents deviates from the country average) can be seen as "cleaned" perceptions. The country averages of the three perception variables represent objective approximations of three dimensions of the regulatory environment. Specifically, the country averages reflect the strictness of the administrative regulatory environment, the difficulty of obtaining information on how to start and run a business, and the difficulty of obtaining credit. In addition, a proxy for the general attitude towards risk in a country is included by averaging values of the risk tolerance variable across all respondents in a country. Deviations from this average risk tolerance are included as an individuallevel determinant. ${ }^{11}$ 
The perception questions can be interpreted in (at least) two different ways by the respondents:

they may think of their own situation or they may think of the general environment for, or attitude towards, entrepreneurship in their country or region. With respect to the stigma of failure variable, a respondent's agreement with the question "Do people who have started a business and failed deserve a second chance?" can be interpreted in two slightly different ways. A direct reading implies that agreement with this statement means that the respondent does not attach a stigma to those who fail. A more audacious reading could be that those who agree might themselves be more likely to take a second chance in the event of a failure of their own venture. Clearly, the first and more obvious interpretation of this question makes this variable a cultural variable representing a respondent's attitude towards failure in general, rather than one that addresses the respondent's own failure. If, however, this attitude is related to consideration for "trying again", following an adverse business outcome, then this variable could also be seen as a primitive measure of the propensity to take risk. Moreover, under the first reading (linked to the attitude towards failure), even though the question clearly refers to the attitude of the respondent, it could be argued that it may also partially reflect the way the respondent perceives these attitudes in his or her environment. Clearly, the expected influence of this variable on the probability of climbing the ladder depends on its interpretation.

Values for the country-specific variables are presented in the first five columns of Table 2. There is substantial cross-country variation. The United States is generally characterised by low values for the factors that hinder the start-up process. More specifically, US citizens are on average more risk tolerant than Europeans, and it appears that there are fewer problems with administrative complexity, insufficient information and financial support. Apart from the US, other risk-tolerant nations include Norway, Denmark, Ireland, and Iceland. Risk aversion is strongest in Slovenia, Portugal, Estonia, Lithuania, and Malta. Inhabitants in France, Greece, Italy, and Portugal are confronted with a relatively unfavourable entrepreneurial climate, as they have the highest scores on administrative complexity, insufficient information and lack of financial support. 


\section{INSERT TABLE 2 HERE}

In terms of the level of economic development, several transition (post-communist) countries (i.e., Poland, Lithuania, Latvia, Hungary, Slovakia, and Estonia) have the lowest per capita income in 2006. ${ }^{12}$ These countries are also characterised by above-average values for administrative complexity, suggesting relatively high levels of red tape. Except for Estonia and the Czech Republic, transition countries perform poorly in terms of access to financial resources. This difficulty of obtaining credit also applies to countries in Southern Europe. Aside from a lack of financial support, the latter group of countries also experience a lack of information regarding firm start-up. Scandinavian countries score relatively low on the administrative complexity variable.

Correlations are presented in Table 3. Although the perception variables show some correlation, problems for further analyses are not expected, given that these values are not excessively high. Note that the risk attitude and stigma of failure variables are not correlated with each other, indicating that they represent two independent constructs.

\section{INSERT TABLE 3 HERE}

For all countries, the percentage of individuals within each of the entrepreneurial engagement levels is given in Table 4. Interesting differences emerge when comparing Europe to the United States. For example, in the United States 30 percent of the respondents indicated that they had never considered setting up a business, while the European average amounts to 51 percent. In addition, the percentages of individuals in the "thinking" and "taking steps" stages in Europe are considerably lower than those in the United States (11 and 4 percent versus 21 and 9 percent, respectively). 


\section{Model}

To capture the entrepreneurial decision as a process consisting of five engagement levels (i.e., "never considered", "thinking”, "taking steps", “young business" and "mature business"), VAN DER ZWAN et al. (2010) use a cumulative logit model. This model assesses the influence of the explanatory variables on the odds (ratio of two probabilities) of being at or beyond a particular engagement level relative to being below this engagement level. Hence, all individuals who failed to make it to a certain engagement level are compared with all individuals who achieved at least this engagement level. The present study instead uses the continuation ratio logit model (AGRESTI, 1984, TUTZ, 1991), in which the categories can only be reached successively because it makes use of conditional probabilities (FAHRMEIR and TUTZ, 1994). According to RABE-HESKETH and SKRONDAL (2008, p. 323) the continuation ratio logit model is appropriate especially in situations where "categories represent stages in some progression". The model assesses the influence of the explanatory variables on the odds of being beyond a particular engagement level relative to being at this engagement level, with both probabilities conditional upon being at or beyond this engagement level. All individuals at a particular engagement level are compared with all individuals who advanced to a higher engagement level. Climbing the entrepreneurial ladder can be considered a sequence of binary transitions: given that one belongs to a certain engagement level, an individual moves either on to the next engagement level, or (un)voluntarily stops at the present level.

Assume an ordered, observed variable, $Y_{i}$, for each individual, i.e. the engagement level of individual $i$ with outcomes $j=1, \ldots, J$. Note that $j=1$ and $j=J$ denote "never considered" and "mature business", respectively. The continuation ratio logit model assumes a conditional modelling of transitions: $\operatorname{Pr}\left(Y_{i}=j \mid Y_{i} \geq j\right)=F\left(\alpha_{j}-X_{i}^{\prime} \beta\right)$ for each $j$ with $\operatorname{Pr}\left(Y_{i}=0 \mid Y_{i} \geq 0\right)=0$ and $\operatorname{Pr}\left(Y_{i}=J \mid Y_{i} \geq J\right)=1 . F($.$) is a cumulative logistic distribution function with a mean of zero and a$ 
variance of $\pi^{2} / 3$. A transition takes place if the underlying latent variable that determines the transition exceeds a transition-specific threshold value (these are denoted by $\alpha_{1}, \ldots, \alpha_{J-1}$ in the formula above; see TUTZ, 1991). This conditional view of the entrepreneurial ladder implies that individuals in "never considered" will only be incorporated in the transition from "never considered" to "thinking", whereas in VAN DER ZWAN et al. (2010) this group of individuals is included in each comparison.

Note that the coefficient vector $\beta$ is the same across all observations and engagement levels. This may be an unrealistic assumption in practice. The coefficients can be made category-specific essentially by performing binary logit regressions and zooming in on four specific positions on the entrepreneurial ladder. For example, the first engagement level ("never considered") can be compared with the four remaining engagement levels, i.e., a logit regression of $\operatorname{Pr}\left(Y_{i}>1\right)$ versus $\operatorname{Pr}\left(Y_{i}=1\right)$. Similarly, three other binary logit regressions can be conducted: $\operatorname{Pr}\left(Y_{i}>2\right)$ versus $\operatorname{Pr}\left(Y_{i}=2\right), \operatorname{Pr}\left(Y_{i}>3\right)$ versus $\operatorname{Pr}\left(Y_{i}=3\right)$ and $\operatorname{Pr}\left(Y_{i}=5\right)$ versus $\operatorname{Pr}\left(Y_{i}=4\right)$.

The results obtained by the continuation ratio logit regression can be interpreted by using logodds ratios that are linear functions of the explanatory variables. These ratios can be expressed as follows: $\log \left(\operatorname{Pr}\left(Y_{i}>j \mid Y_{i} \geq j\right) / \operatorname{Pr}\left(Y_{i}=j \mid Y_{i} \geq j\right)\right)=X_{i}^{\prime} \beta+\alpha_{j}$. Given a positive coefficient and holding all other variables constant, an increase in this particular variable raises the likelihood of belonging to a higher engagement level relative to the likelihood of belonging to the present engagement level, conditional on being at or beyond the present engagement level. One can interpret the results from the four binary logit regressions in the same way.

In fact, we compare the entrepreneurial engagement of randomly selected individuals at the time of the survey (January 2007). For some individuals their current engagement level will also be their final engagement level; others, however, will at some moment advance to a higher level of entrepreneurial engagement (censored observations). One may also take into account individuals who are in "gave up", "failure", or "sell-off". Unfortunately, there is no information on whether individuals in the "gave up" stage ultimately reached "thinking" or "taking steps". The same holds true for the 


\section{Analysis and Results}

Table 5 displays the results of the continuation ratio logit regression (the parsimonious "overall" model) in the first column and the four binary logit regressions in the last four columns. Standard errors are clustered on countries. Hence, they are robust to heteroskedasticity and observations within countries are allowed to be correlated. The five models include the individual-level variables, the urban region, and country dummies. Hence, country effects are investigated by including 27 country dummies (representing the EU-25 Member States, Norway and Iceland), with the United States as the benchmark country. The outcomes are discussed below.

\section{INSERT TABLE 5 HERE}

\subsection{Individual-level Factors}

\section{Gender}

Focusing on the continuation ratio logit model, it is found that gender is an important factor for achieving entrepreneurial progress: being a man increases the odds of being beyond, rather than being at, a specific engagement level (conditional on being at or beyond this level and all other variables equal) by $\exp (0.629)=1.878$. Apart from the coefficient of the squared age term, this makes gender the individual-level variable with the highest coefficient in absolute terms. However, the pattern is not consistent across the four binary models. The significance of gender in the "overall" model can be attributed almost entirely to an advantage for men (relative to women) in the transitions from "never considered" to "thinking" (second column of results) and from "thinking" to "taking steps" (third 
column of results). Given that an individual undertakes activities to start up a business, men are only $\exp (0.208)=1.231$ times more likely than women to make transitions to a higher entrepreneurial engagement level (this coefficient is significant at the 5 percent level; see penultimate column). Equal odds for men and women to be in the "mature business" stage relative to the "young business" stage (given that the "young business" stage has been reached; see last column) even suggest similar survival chances across gender. It could be that the much higher propensity of men to make the first two transitions is driven by other factors (that are not controlled for, but) that may be related to gender such as opportunity recognition or entrepreneurial self-efficacy. In a similar fashion, the smaller gender effect for the third transition and the absence of a gender effect for the last transition do not mean that gender does not play a role. Gender may still moderate the relationship between other factors and entrepreneurial engagement or progress. ${ }^{13}$

Age

Age shows an inverse U-shaped relationship with entrepreneurial progress. The turning point of age is at 43 years. Above this age, the likelihood of advancing beyond a given engagement level decreases, i.e., individuals are less likely to belong to a higher level of entrepreneurial engagement. This effect of age on the transition probability is primarily influenced by the first transition: the turning point at which the transition to the "thinking" stage becomes less likely is at the age of 31 years, whereas the turning points for other transitions are much higher.

\section{Education}

The results in the first column of Table 5 reveal that there is an overall positive effect of education level on entrepreneurial progress, indicating that stepping up the entrepreneurial ladder is enhanced by a higher level of education. Again, there are differences across the four binary logit regressions. The impact of education level is significantly positive for the first transition ("never considered" to "thinking"), insignificant for the next transition ("thinking" to "taking steps") and significantly negative for the final two switches on the entrepreneurial ladder ("taking steps" to "young business" and "young business" to "mature business"). This means that a higher level of education is important mainly in becoming aware of entrepreneurship as a possible career option, but 
appears detrimental for advancing to later stages of entrepreneurial engagement, where relevant experience and skills may become more important. Similarly, entrepreneurship education is important for forming entrepreneurial intentions; it does not have an effect on subsequent transitions.

\section{Role models}

Table 5 shows that, overall, self-employed parents positively contribute to advancement in the entrepreneurial process. Investigating the differential impacts of this variable across the engagement levels, it turns out that self-employed parents are of help during the early phase of setting up a business. More precisely, they are important in the entrepreneurial intention and taking steps stages, but are no longer of influence for the start-up and development of the business. This is in line with DAVIDSSON and HONIG (2003), who find that while strong ties are particularly important for shaping children's preferences, in later stages weak ties are more influential.

\section{Risk tolerance and stigma of failure}

The significant impact of risk tolerance in the continuation ratio logit model can be attributed to the significant coefficients of risk tolerance in the transitions from "never considered" to "thinking" and from "taking steps" to "young business". Stigma of failure does have an impact on overall advancement in the entrepreneurial process, although to some extent it holds back individual's intentions to start up a business (at the 5 percent significance level).

\section{Perceived barriers to entrepreneurship}

In the "overall" model, the perception of administrative complexities negatively influences the probability of being beyond a given engagement level, whereas there is a small negative impact for the perception of lack of financial support (at the 10 percent level) and no discriminating effect for the perception of insufficient information. Focusing on the four binary regressions, it appears that the perceived administrative burden is a real barrier for developing entrepreneurial intentions and taking steps to start a business. The perception of a lack of financial support hinders individuals in taking steps to start a business, but is insignificant in all other comparisons. This could be an experience effect, where people only learn about the existence of a barrier after having experienced it themselves. 
To conclude, none of the perceived barriers play a hindering role in transforming nascent activities into established businesses (from "taking steps" to "young business") and in the continuation and development of businesses (from "young business" to "mature business").

\subsection{Regional Factor: Urban versus Rural Areas}

Living in a metropolitan or urban area decreases the "overall" probability of making entrepreneurial progress, albeit at the 10 percent significance level. Hence, living in a metropolitan or urban region puts a brake on overall entrepreneurial progress to some extent. Glancing at the results for the transitions between the separate stages, the urban dummy variable has a significant negative coefficient for the transition from "thinking" to "taking steps" (at the 10 percent level) and from "taking steps" to "young business" (at the 5 percent level). These findings may point to the strength of negative competition effects cancelling out positive agglomeration effects.

\subsection{Country Dummies}

The first column of Table 5 shows that there are only two countries (Hungary and Iceland) that have higher odds of climbing the entrepreneurial ladder than the United States and two countries that are on par with the US (Czech Republic and Greece). Furthermore, individuals in Cyprus, Estonia, Latvia, Poland, and Slovakia are able to keep up with the entrepreneurial progress of US citizens, given the corresponding $\log$ odds of at most -0.150 . On the other hand, individuals from Austria, Belgium, France, Luxembourg, Malta, Slovenia, and Spain have a relatively low likelihood of moving beyond a given engagement level (the log odds of these countries are below -0.500 ). Hence, it seems that low-income countries perform relatively well in shaping conditions for entrepreneurial progress, as seven out of the nine aforementioned countries have a lower per capita income than the average value, as displayed in Table 2 (exceptions are Greece and Iceland). Welfare states such as Austria, Belgium, France, and Luxembourg, characterised by stringent regulatory environments, discourage individuals from advancing in the entrepreneurial process, thereby missing out on opportunities to enhance the competitiveness of these regions. In welfare states economic incentives for opportunitybased and necessity-based entrepreneurship are often reduced (HENREKSON, 2005) and entry regulation tends to be relatively strict. 
The overall effects, as described above, do not adequately capture the unique effects across the transitions between specific engagement levels. For example, in the United States relatively many individuals switch from "never considered" to "thinking about" starting a business. In fact, all countries show significant lower odds of a transition between these stages. This is particularly the case for Austria, Belgium, Finland, France, Luxembourg, Malta, Portugal, and Spain (with log-odds below $-1.400)$. Hence, these countries should pay more attention to creating awareness of entrepreneurship as a possible career option. The position of the United States weakens for the transition between "thinking" and "taking steps": there are only five countries (Denmark, Latvia, Malta, Slovakia, and Slovenia) with significant negative log-odds. This indicates that individuals in these countries have a hard time acting upon and materializing their entrepreneurial dreams.

Regarding the switch from "taking steps" to "young business", almost all countries have higher odds than, or are on par with, the United States. In particular, individuals from Belgium, Cyprus, Czech Republic, Germany, Greece, Hungary, Iceland, Ireland, Norway, Portugal, Slovenia, and Spain have a high likelihood (log-odds above 1.000) of advancement beyond the "taking steps" stage. It seems that there are few impediments that deter individuals from taking their start-up a step further and developing it into a young established firm in these countries. Lithuania and Slovakia have lower and equal odds, respectively, as compared to the United States and, hence, are weak performers.

Finally, regarding the transition from "young business" to "mature business", survival chances seem to be highest in Belgium, Iceland, Malta, and Poland (log-odds at least 0.700), whereas they are lowest in Portugal.

To conclude, in the relatively weakly regulated United States, individuals have a high likelihood of thinking about starting a business, but have difficulties moving to higher levels of entrepreneurial engagement. Particularly, transforming nascent and start-up activity into viable young firms appears relatively difficult in the United States. Overall, there is substantial heterogeneity between countries. The subsequent section aims to explain this heterogeneity.

\subsection{Country-level Factors}

Table 6 shows the results of the continuation ratio logit regression and four binary logit 
regressions, including country-level variables instead of country dummies. ${ }^{14}$ More country-specific variables could have been included in the model, but with only 28 countries, a parsimonious model is preferred to an over-fitted model with a surplus of variables. ${ }^{15}$

\section{INSERT TABLE 6 HERE}

In the "overall" model the continuation ratio coefficients show that risk tolerance has a significant positive effect on a country's entrepreneurial progress (at the 1 percent significance level), while per capita income has a negative effect (albeit at the 10 percent significance level). The three environmental variables do not have a significant impact on the overall process. Investigating the binary logit regressions, there is a negative effect of the level of economic development (measured by per capita income) on the likelihood of switching from "never considered" to "thinking" (the trough of the $\mathrm{U}$-shape is at an irrelevant per capita income of $\$ U S 46,098$ ) and a positive effect on the likelihood of making the transition from "taking steps" to "young business" (the trough of the inverse U-shape is at \$US 32,049). This means that individuals in more developed countries are less likely to consider entrepreneurship as a viable career option, but that once they are nascent entrepreneurs there is a relatively high likelihood of transforming these nascent activities into a young business. When replacing the income variable with a transition dummy in our model specification, a more nuanced picture emerges regarding country differences. That is, the transition dummy has a significant positive continuation ratio coefficient of 0.538 at the 1 percent significance level. In addition, significant positive coefficients of this dummy variable are found for the first transition from "never considered" to "thinking" ( 0.905 at the 1 percent level) and for the last transition from "young business" to "mature business" (0.577 at the 10 percent level). Hence, these findings support the claim of BOWEN and DE CLERCQ (2008) that there is potential for growth opportunities in transition economies.

It is interesting to see whether making progress through the engagement levels (that may be seen as the entrepreneurial contribution to competitiveness) is related to a specific indicator of 
competitiveness, here: labour productivity growth per person employed in 2006, of which the values are displayed in the last column of Table 2. Labour productivity growth does not influence overall progress, but it has a positive significant coefficient (at the 10 percent level) for the transition from "taking steps" to "young business". In other words, individuals in countries characterised by higher labour productivity growth are more likely to develop their start-up into a viable young business. ${ }^{16}$

Remarkable is that a country's level of administrative complexity does not play a role in achieving entrepreneurial progress, which is in sharp contrast to the impact of the individual perception of administrative complexity, as shown in Table 5. This suggests that it is not the actual level of administrative complexity that forms a barrier, but rather the subjective perception of this complexity. Furthermore, the access to finance appears to have a negative effect on the likelihood of making a transition from "thinking" to "taking steps" and from "young business" to "mature business". Indeed, these are the stages in which generally there is a high need for financial resources. Unexpectedly, a country's level of insufficient information positively affects the transition from "thinking" to "taking steps" and from "taking steps" to "young business". This may be an experience effect, as people will probably only find out about a lack of information when they are themselves actively involved in entrepreneurial activity.

We perform a few additional checks. First, we examine the influence of an institutional indicator, i.e. the size of the government. More precisely, we investigate the impact of total government expenses as a fraction of total GDP on entrepreneurial progress. We retrieve these data from the World Bank (World Development Indicators 2008). Although more government expenses may imply fewer entry barriers, it has also been argued that welfare economies tend to reduce incentives for opportunity-based and necessity-based entrepreneurship (HENREKSON, 2005). For example, AIDIS et al. (2010) find a significant negative relationship between the size of the government and nascent entrepreneurship. In addition, KOELLINGER and MINNITI (2009) find that higher unemployment benefits negatively influence opportunity-based and necessity-based nascent entrepreneurship. In our case, it turns out that government expenses as fraction of GDP do not have an impact in the continuation ratio logit regression and the four binary logit regressions at the 10 percent 
significance level. Results are available from the authors upon request.

In a next exercise, we investigate how sensitive our results are to the inclusion of the US. Whereas the results without the US are not reported in the present paper, we note a few changes as compared to Tables 5 and 6 . In general, these changes only involve coefficients that are significant at the 10 percent level in Tables 5 and 6. Specifically, a few coefficients lose their significance in Table 5 (education in the third transition from "taking steps" to "young business", the urban dummy in the "overall" model and the second transition from "thinking" to "taking steps", and perceived financial barriers in the "overall" model). In Table 6, it is per capita income that loses its significance in the "overall" model and in the third transition from "taking steps" to "young business" (both the single and quadratic term).

\section{Conclusion}

Using data from the 2007 Flash Eurobarometer Survey on Entrepreneurship, this study investigates entrepreneurial progress through five stages of entrepreneurial engagement and finds evidence for both individual and cross-country differences. With respect to individual-level factors, women have a lower probability of achieving entrepreneurial progress than men, but this slower progress is only visible in the early stages of entrepreneurial involvement. That is, the transitions from "never considered" to "thinking" and from "thinking" to "taking steps" are much more difficult to take for women than for men, but there is hardly a gender difference at higher stages of entrepreneurial involvement. Self-employed parents are valuable for creating entrepreneurial intentions and stimulating start-up activity, but no longer have an influence at later stages. Regarding the influence of individual perceptions of barriers to entrepreneurship (in terms of administrative complexity, lack of relevant information and lack of financial support) on entrepreneurial progress, we see that an individual's perceived administrative complexity lowers the likelihood of making a transition to the "thinking" and "takings steps" stages. A perceived lack of financial support lowers nascent entrepreneurial activity. Interestingly, living in an urban area lowers the likelihood of entrepreneurial progress. This may point to competition effects that reduce the lifespan of new ventures or possibly 
discourage potential entrepreneurs.

These results prompt some tentative thoughts in terms of policy. First, the results for gender suggest that if policies aimed at encouraging women to pursue an entrepreneurial career are to be envisaged, these measures should concentrate on the possible bottlenecks holding back women at the very early stages. Although concrete policy recommendations would require further investigation and are beyond the scope of this study, current results hint at the possible positive impact for women of role models and initiatives aimed at bringing to their attention the possibility of an entrepreneurial career. In other words, "soft" measures with a strong informational and inspirational orientation, rather than harder measures with a "positive discrimination" content, seem in order. Second, the hindering role of perceptions of administrative complexity (here seen as deviation from the average) for undertaking nascent activities, which is in sharp contrast to the role of administrative complexity as a country-level variable, points to "perception" as a central concept. For this reason, if perceptions deviate from the actual environmental setting to a considerable extent, this may be a consideration for policy intervention in the form, again, of actions aimed at making information more transparent and readily available to potential entrepreneurs. However, these policy implications should be taken with care because they do not necessarily extrapolate to periods that are characterized by less economic growth than was experienced in 2007.

In addition, evidence is found for country effects on entrepreneurial progress. In the United States, for example, there is a high inclination to think about starting up a business, but a different picture emerges in the case of the materialization of these thoughts (actually starting up a business). This is illustrated by the fact that, relative to the United States, it is just as easy or easier in all European countries in our data set to make the transition from nascent entrepreneurial activity to a young business. Aside from including country dummies, the effect of country-level factors on entrepreneurial progress is also investigated. One of the main findings is that a country's attitude toward risk plays an important role in explaining entrepreneurial progress across countries. In risktolerant countries, it is generally easier to make entrepreneurial progress than in countries with a riskaverse attitude. Indeed, Lithuania, a country that scores low in terms of entrepreneurial progress, is 
also characterised by a relatively low level of risk tolerance. Furthermore, Portugal, a country where it is difficult to develop a company beyond the young business stage, is characterised by the lowest level of risk tolerance. This is in line with HOFSTEDE (1985), who finds that Portugal has the highest score on the Uncertainty Avoidance Index. Risk tolerance may also play a role in explaining the position of the United States in this study. Although US citizens have an advantage over Europeans in the early stage of entrepreneurship, in which people start to think about entrepreneurship as an interesting career alternative, in later stages they are not more advanced. Indeed, although the American people have the highest level of risk tolerance, this risk tolerance only benefits them in the first stages of entrepreneurship (see Table 6). The negative impact of risk aversion is difficult to discuss from a policy perspective without further insights into the real source of risk aversion and its variation across countries. Given the way risk tolerance is proxied here ${ }^{17}$, it most likely captures at least two dimensions: the intrinsic or cultural nature of such attitude, and another dimension more closely linked with the legal or social consequences of bankruptcy. While changing the first dimension is at best a long-term endeavour, bankruptcy law and procedures may play a role in the second dimension. Again, an investigation of this issue and of its policy implications is beyond the information and analysis in the present study.

Furthermore, a country's lack of financial support negatively affects the transitions from thinking about setting up a business to nascent entrepreneurship and from nascent entrepreneurship to having a young business. This could indicate that a high number of firms are not actually started up because there is inadequate financial support for aspiring entrepreneurs. This could in part explain the low levels of entrepreneurial progress in France and Portugal, countries having the highest scores for lack of financial support (see Table 2). On the other hand, the success of Iceland across the stages could (aside from an above-average level of risk tolerance) partly be attributed to the good financial support in that country. In fact, Iceland scores lowest for lack of financial support (see Table 2).

The present study investigated the influence of a range of important factors at different aggregation levels on entrepreneurial progress. Nevertheless, there may be other variables that play a role in explaining entrepreneurial progress that could be taken into account in future research on this 
Acknowledgments: The authors would like to thank André van Stel and three anonymous reviewers for their helpful suggestions, as well as the participants of the Workshop on Entrepreneurship and Regional Competitiveness (Orkestra, Basque Institute of Competitiveness in San Sebastian, 19-20 June 2009). The views expressed here are those of the authors and should not be attributed to the European Commission. For the first three authors, the paper has been written in cooperation with the research program SCALES, which is carried out by EIM and is financed by the Dutch Ministry of Economic Affairs.

\section{References}

ACS Z. J. and ARMINGTON C. (2004) The impact of geographic differences in human capital on service formation rates, Journal of Urban Economics 56, 244-278.

ACS Z. J., ARMINGTON C., and ZHANG T. (2007) The determinants of new-firm survival across regional economies: the role of human capital stock and knowledge spillover, Papers in Regional Science 86(3), 367391.

AGRESTI A. (1984) Analysis of Ordinal Categorical Data. New York: Wiley. 
AIDIS R., ESTRIN S. and MICKIEWICZ T.M. (2010) Size matters: entrepreneurial entry and government, Small Business Economics, DOI: 10.1007/s11187-010-9299-y.

AJZEN I. (1991) The theory of planned behaviour, Organizational Behavior and Human Decision Processes 50(2), 179-211.

ALLEN I.E., ELAM A., LANGOWITZ, N. and DEAN, M. (2008) Global Entrepreneurship Monitor. 2007 Report on women and entrepreneurship, The Center for Women's Leadership, Babson College.

ARENIUS P. and MINNITI M. (2005) Perceptual variables and nascent entrepreneurship, Small Business Economics 24(3), 233-247.

ARMINGTON C. and ACS Z. J. (2002) The determinants of regional variation in new firm formation, Regional Studies 36(1), 33-45.

AUDRETSCH D. B. and DOHSE D. (2007) Location: a neglected determinant of firm growth, Review of World Economics 143(1), 79-107.

AUDRETSCH D. B. and KEILBACH M. (2004) Entrepreneurship capital and economic performance, Regional Studies 38(8), 949-959.

BAPTISTA R., ESCÁRIA V. and MADRUGA P. (2008) Entrepreneurship, regional development and job creation: the case of Portugal, Small Business Economics 30, 49-58.

BATES T. (1990) Entrepreneur human capital inputs and small business longevity, Review of Economics and Statistics 72(4), 551-559.

BATES T. (1995) Self-employment entry across industry groups, Journal of Business Venturing 10(2), 143-156.

BAUM J. R., OLIAN J. D., EREZ M., SCHNELL E. R., SMITH K. G., SIMS H. P., SCULLY J. S. and SMITH K. A. (1993) Nationality and work role interactions: a cultural contrast of Israeli and US entrepreneurs' versus managers’ needs, Journal of Business Venturing 8(6), 499-512.

BAUMOL W. J. (1990) Entrepreneurship: productive, unproductive and destructive, Journal of Political Economy 98(5), 893-921.

BEUGELSDIJK S. and NOORDERHAVEN N. (2005) Personality characteristics of self-employed; An empirical study, Small Business Economics 24(2), 159-167.

BLANCHFLOWER D. G. (2000) Self-employment in OECD countries, Labour Economics 7(5), 471-505.

BLANCHFLOWER D. G. and OSWALD A. J. (1998) What makes an entrepreneur? Journal of Labor Economics 16(1), 26-60. 
BLANCHFLOWER D. G. and SHADFORTH C. (2007) Entrepreneurship in the UK, IZA Discussion Paper, No. 2818.

BLANCHFLOWER D. G., OSWALD A. and STUTZER A. (2001) Latent entrepreneurship across nations, European Economic Review 45(4-6), 680-691.

BLAU D. (1987) A time-series analysis of self-employment in the United States, Journal of Political Economy 95(3), 445-467.

BORJAS G. J. and BRONARS S. G. (1989) Consumer discrimination and self-employment, Journal of Political Economy 97(3), 581-605.

BOSMA N., VAN PRAAG M., THURIK R. and DE WIT G. (2004) The value of human and social capital investments for the business performance of startups, Small Business Economics 23(3), 227-236.

BOWEN H. P. and DE CLERCQ D. (2008) Institutional context and the allocation of entrepreneurial effort, Journal of International Business Studies 39(4), 747-767.

BOYD N. G. and VOZIKIS G. S. (1994) The influence of self-efficacy on the development of entrepreneurial intentions and actions, Entrepreneurship: Theory \& Practice 18(4), 63-77.

BRÜDERL J. and PREISENDÖRFER P. (1998) Network support and the success of newly founded business, Small Business Economics 10(3), 213-225.

BRÜDERL J., PREISENDÖRFER P. and ZIEGLER R. (1992) Survival chances of newly founded business organizations, American Sociological Review 57(2), 227-242.

BURKE A. E., FITZROY F. R. and NOLAN M. A. (2002) Self-employment wealth and job creation: The roles of gender, non-pecuniary motivation and entrepreneurial ability, Small Business Economics 19(3), 255-270.

CALIENDO M., FOSSEN F. and KRITIKOS A. (2009) Risk attitudes of nascent entrepreneurs-new evidence from an experimentally validated survey, Small Business Economics 32(2), 153-167.

CALIENDO M., FOSSEN F. and KRITIKOS A. (2010) The impact of risk attitudes on entrepreneurial survival, Journal of Economic Behavior \& Organization 76, 45-63.

CAPELLERAS J.-L., MOLE K. F., GREENE F. J. and STOREY D. J. (2008) Do more heavily regulated economies have poorer performing new ventures? Evidence from Britain and Spain, Journal of International Business Studies 39(4), 688-704.

CARREE M. A., VAN STEL A. J., THURIK A. R. and WENNEKERS A. R. M. (2002) Economic development and business ownership: an analysis using data of 23 OECD countries in the period 1976-1996, Small Business Economics 19(3), 271-290. 
CARREE M. A., VAN STEL A. J., THURIK A. R. and WENNEKERS A. R. M. (2007) The relationship between economic development and business ownership revisited, Entrepreneurship and Regional Development 19(3), 281-291.

CARREE M.A. and THURIK A.R. (2010) The impact of entrepreneurship on economic growth, in AUDRETSCH D. B. and ACS Z. J. (Eds) Handbook of Entrepreneurship Research. Berlin/Heidelberg: Springer Verlag, 557-594.

CARTER N. M., GARTNER W. B. and REYNOLDS P. D. (1996) Exploring start-up event sequences, Journal of Business Venturing 11(3), 151-166.

CLARK B. W., DAVIS C. H. and HARNISH V. C. (1984) Do courses in entrepreneurship aid in new venture creation? Journal of Small Business Management 22(2), 26-31.

COLLINS-DODD C., GORDON I. M. and SMART C. (2004) Further evidence on the role of gender in financial performance, Journal of Small Business Management 42(4), 395-417.

COOPER A. C., GIMENO-GASCON F. J. and WOO C.Y. (1994) Initial human and financial capital as predictors of new venture performance, Journal of Business Venturing 9(5), 371-395.

COWLING M. (2000) Are entrepreneurs different across countries? Applied Economics Letters 7(12), 785-789.

CRAMER J.S., HARTOG J., JONKER N. and VAN PRAAG C.M. (2002) Low risk aversion encourages the choice for entrepreneurship: an empirical test of a truism, Journal of Economic Behavior \& Organization 48(1), 29-36.

CROSA B., ALDRICH H. E. and KEISTER L. A. (2002) Is there a wealth effect? Financial and human capital determinants of business start-ups, in BYGRAVE W. D., BRUSH C., DAVIDSSON P., FIET J., GREENE P., HARRISON R., LERNER M., DALE MEYER G., SOHL J. and ZACHARAKIS A. (Eds) Frontiers of Entrepreneurship Research 2002. Wellesley, MA: Babson College.

DAVIDSSON P. (1991) Continued entrepreneurship: Ability, need, and opportunity as determinants of small firm growth, Journal of Business Venturing 6(6), 405-429.

DAVIDSSON P. (1995) Determinants of entrepreneurial intentions, Paper prepared for the RENT IX Workshop. Piacenza, Italy, Nov. 23-24.

DAVIDSSON P. (2006) Nascent entrepreneurship: empirical studies and developments, Foundations and Trends in Entrepreneurship 2(1), 1-76.

DAVIDSSON P. and HONIG B. (2003) The role of social and human capital among nascent entrepreneurs, Journal of Business Venturing 18(3), 301-331. 
DE WIT G. and VAN WINDEN F. (1989) An empirical analysis of self-employment in the Netherlands, Small Business Economics 1(4), 263-272.

DELMAR F. and DAVIDSSON P. (2000) Where do they come from? Prevalence and characteristics of nascent entrepreneurs, Entrepreneurship \& Regional Development 12(1), 1-23.

DIMOV D. (2010) Nascent entrepreneurs and venture emergence: Opportunity confidence, human capital, and early planning, Journal of Management Studies 47(6), 1123-1153.

DJANKOV S., LA PORTA R., LOPEZ-DE-SILANES F. and SHLEIFER A. (2002) The regulation of entry, The Quarterly Journal of Economics 117(1), 1-37.

DUNN T. and HOLTZ-EAKIN D. (2000) Financial capital, human capital, and the transition to selfemployment: Evidence from Intergenerational Links, Journal of Labor Economics 18(2), 282-305.

EUROPEAN COMMISSION (2008) European Competitiveness Report 2008, Brussels: DG Enterprise and Industry.

EUROPEAN COMMISSION (2009) European Competitiveness Report 2009, Brussels: DG Enterprise and Industry.

EVANS D. S. and JOVANOVIC B. (1989) An estimated model of entrepreneurial choice under liquidity constraints, Journal of Political Economy 97(4), 808-827.

EVANS D. S. and LEIGHTON L. S. (1989) Some empirical aspects of entrepreneurship, American Economic Review 79(3), 519-535.

EVANS D. S. and LEIGHTON L. S. (1990) Small business formation by unemployed and employed workers, Small Business Economics 2, 319-330.

FAHRMEIR L. and TUTZ G. (1994) Multivariate Statistical Modeling based on Generalized Linear Models. New York: Springer.

FAIRLIE R.W. and ROBB A. M. (2009) Gender differences in business performance: evidence from the Characteristics of Business Owners survey, Small Business Economics 33, 375-395.

FALCK O. (2007) Survival chances of start-ups, do regional conditions matters? Applied Economics 39(16), 2039-2048

FISCHER E.M., REUBER A.R. and DYKE L.S. (1993) A theoretical overview and extension of research on sex, gender and entrepreneurship, Journal of Business Venturing 8(2), 151-168.

FREYTAG A. and THURIK R. (2007) Entrepreneurship and its determinants in a cross-country setting, Journal of Evolutionary Economics 17(2), 117-131. 
FRITSCH M. and MUELLER P. (2008) The effects of new business formation on regional development over time: the case of Germany, Small Business Economics 30(1), 15-29.

FRITSCH M., BRIXY U. and FALCK O. (2006) The effect of industry, region and time on new business survival - a multi-dimensional analysis, Review of Industrial Organization 28(3), 285-306.

GEORGELLIS Y., SESSIONS J. and TSITSIANIS N. (2005) Windfalls, wealth, and the transition to selfemployment, Small Business Economics 25(5), 407-428.

GIMENO J., FOLTA T. B., COOPER A. C. and WOO C. Y. (1997) Survival of the fittest? Entrepreneurial human capital and the persistence of underperforming firms, Administrative Science Quarterly 42(4), 750783.

GORMAN G., HANLON D. and KING W. (1997) Some research perspectives on entrepreneurship education, enterprise education and education for small business management: A ten-year literature review, International Small Business Journal 15(3), 56-77.

GRILO I. and IRIGOYEN J.-M. (2006) Entrepreneurship in the EU: To wish and not to be, Small Business Economics 26(4), 305-318.

GRILO I. and THURIK A. R. (2005) Latent and actual entrepreneurship in Europe and the US: Some recent developments, International Entrepreneurship and Management Journal 1(4), 441-459.

GRILO I. and THURIK A. R. (2008) Determinants of entrepreneurial engagement levels in Europe and the US, Industrial and Corporate Change 17(6), 1113-1145.

GUESNIER B. (1994) Regional variation in new firm formation in France, Regional Studies 28(4), 347-358.

HENREKSON M. (2005) Entrepreneurship: a weak link in the welfare state? Industrial and Corporate Change 14(3), 437-467.

HESSELS J., GRILO I., THURIK R. and VAN DER ZWAN P. (2011) Entrepreneurial exit and entrepreneurial engagement, Journal of Evolutionary Economics, forthcoming..

HOFSTEDE G. (1985) The interaction between national and organizational value systems, Journal of Management Studies 22(4), 347-357.

HOUT M. and ROSEN H. (2000) Self-employment, family background, and race, Journal of Human Resources 35(4), 670-692.

JACK S. L. and ANDERSON R. (1998) Entrepreneurship education within the condition of entreprenology. Paper presented at the Proceedings of the Conference on Enterprise and Learning, Aberdeen. 
JOHNSON P. and PARKER S. (1996) Spatial variations in the determinants and effects of firm births and deaths, Regional Studies 30(7), 679-688.

KALLEBERG A. L. and LEICHT K. T. (1991) Gender and organizational performance: determinants of small business survival and success, Academy of Management Journal 34(1), 136-161.

KELLEY D. J., BOSMA N. and AMORÓS J.E. (2011) Global Entrepreneurship Monitor 2010: Global Report. Babson College, US, Universidad del Desarrollo, Chile, and London Business School, London.

KIHLSTROM R. E. and LAFFONT J.-J. (1979) A general equilibrium entrepreneurial theory of firm formation based on risk aversion, Journal of Political Economy 87(4), 719-748.

KIM P. H., ALDRICH H. E. and KEISTER L. A. (2003) If I were rich? The impact of financial and human capital on becoming a nascent entrepreneur, Paper presented at the Annual Meeting of the American Sociological Association, Atlanta.

KITSON M., MARTIN R. and TYLER P. (2004) Regional competitiveness: an elusive yet key concept? Regional Studies 38(9), 991-999

KLAPPER L., LAEVEN L. and RAJAN R. (2006) Entry regulation as a barrier to entrepreneurship, Journal of Financial Economics 82, 591-629.

KOELLINGER P.D. and MINNITI M. (2009) Unemployment benefits crowd out nascent entrepreneurial activity, Economic Letters 103, 96-98.

KOELLINGER P., MINNITI M. and SCHADE C. (2007) “I think I can, I think I can”: Overconfidence and entrepreneurial behaviour, Journal of Economic Psychology 28(4), 502-527.

KOLVEREID L. and MOEN O. (1997) Entrepreneurship among business graduates: does a major in entrepreneurship make a difference? Journal of European Industrial Training 21(4), 154-160.

KOURILSKY M. L. and WALSTAD W. B. (1998) Entrepreneurship and female youth: knowledge, attitudes, gender differences, and educational practices, Journal of Business Venturing 13(1), 77-88.

KRUEGER N. and BRAZEAL D. V. (1994) Entrepreneurial potential and potential entrepreneurs, Entrepreneurship Theory and Practice 18(3), 91-104.

KRUEGER N. F., REILLY M. D. and CARSRUD A. L. (2000) Competing models of entrepreneurial intentions, Journal of Business Venturing 15(5-6), 411-432.

KRUGMAN P. (1991) Myths and realities of U.S. competitiveness, Science 254(5033), 811-815.

KURATKO D. F. (2005) The emergence of entrepreneurship education: development, trends, and challenges, Entrepreneurship: Theory \& Practice 29(5), 577-597. 
LANGOWITZ N. and MINNITI M. (2007) The entrepreneurial propensity of women, Entrepreneurship: Theory \& Practice 31(3), 341-364.

LEE L., WONG P. K., FOO M.D. and LEUNG A. (2011) Entrepreneurial intentions: The influence of organizational and individual factors, Journal of Business Venturing 26(1), 124-136.

LÉVESQUE M. and MINNITI M. (2006) The effect of aging on entrepreneurial behaviour, Journal of Business Venturing 21, 177-194.

LICHTENSTEIN B. B., CARTER N. M., DOOLEY K. J. and GARTNER W. B. (2007) Complexity dynamics of nascent entrepreneurship, Journal of Business Venturing 22(2), 236-261,

LUSSIER R. N. (1995) A nonfinancial business success versus failure prediction model for young firms, Journal of Small Business Management 33(1), 8-20.

LÜTHJE C. and FRANKE N. (2003) The 'making' of an entrepreneur: testing a model of entrepreneurial intent among engineering students at MIT, $R \& D$ Management 33(2), 135-147.

MARSHALL A. (1920), Principles of Economics, London: MacMillan.

MASUDA T. (2006) The determinants of latent entrepreneurship in Japan, Small Business Economics 26(3), 227-240.

MATTHEWS C. H. and MOSER S. B. (1996) A longitudinal investigation of the impact of family background and gender on interest in small firm ownership, Journal of Small Business Management 34(2), 29-43.

MILLER A. (1987) New ventures: A fresh emphasis on entrepreneurial education, Survey of Business 23(1), 4-8.

MILLER R. A. (1984) Job matching and occupational choice, Journal of Political Economy 92(6), 1086.

MINNITI M. (2005) Entrepreneurship and network externalities, Journal of Economic Behavior and Organization $\underline{57}(1), 1-27$.

MINNITI M. (2010) Female entrepreneurship and economic activity, European Journal of Development Research 22(3), 294-312.

MUGLER J. (2000) The climate for entrepreneurship in European countries in transition, in SEXTON D.L. and LANDSTRÖM H. (Eds) The Blackwell Handbook of Entrepreneurship (Oxford/Malden: Blackwell), pp. $150-175$.

NOORDERHAVEN N., THURIK R., WENNEKERS S. and VAN STEL A.J. (2004) The role of dissatisfaction and per capita income in explaining self-employment across 15 European countries, Entrepreneurship: Theory and Practice 28(5), 447-466. 
NORTON W. and MOORE W. (2006) The influence of entrepreneurial risk assessment on venture launch or growth decisions, Small Business Economics 26(3), 215-226.

OOSTERBEEK H., VAN PRAAG C. M. and IJSSELSTEIN A. (2007) The impact of entrepreneurship education on entrepreneurship competencies and intentions: An evaluation of the junior Achievement Student Mini-Company Program. Tinbergen Discussion Paper TI 2008-038/3.

PARKER S. C. (2009) The economics of entrepreneurship. Cambridge: Cambridge University Press.

PARKER S. C. and ROBSON M. T. (2004) Explaining international variations in self-employment: evidence from a panel of OECD, Southern Economic Journal 71(2), 287-301.

PARKER S. C. and BELGHITAR Y. (2006) What happens to nascent entrepreneurs? An Econometric Analysis of the PSED, Small Business Economics 27(1), 81-101.

PETERMAN N. E. and KENNEDY J. (2003) Enterprise education: Influencing students' perceptions of entrepreneurship, Entrepreneurship: Theory \& Practice 28(2), 129-144.

POLITIS D. (2005) The process of entrepreneurial learning: A conceptual framework, Entrepreneurship: Theory \& Practice 29(4), 399-424.

PORTER M. (1990) The competitive advantage of nations. New York: Free Press.

RABE-HESKETH S. and SKRONDAL A. (2008) Multilevel and longitudinal modeling using Stata. 2nd edition. Stata Press.

REES H. and SHAH A. (1986) An empirical analysis of self-employment in the U.K., Journal of Applied Econometrics 1(1), 95-108.

RASPE O. and VAN OORT F. G. (2008) Firm growth and localized knowledge externalities, The Journal of Regional Analysis and Policy 38(2), 100-116.

REYNOLDS P. D. (1997) Who starts new firms? - Preliminary explorations of firms-in-gestation, Small Business Economics 9(5), 449-462.

REYNOLDS P. D., BYGRAVE W. D., AUTIO E., COX L. W. and HAY M. (2002) Global Entrepreneurship Monitor, 2002 Babson Park, MA: Babson College, London: London Business School and Kansas City, MO: Kauffman Foundation.

REYNOLDS P. D., HAY M. and CAMP S. M. (1999), Global Entrepreneurship Monitor: 1999 Executive Report, Babson College, London Business School, Kauffman Center for Entrepreneurial Leadership. 
REYNOLDS P., CARTER N., GARTNER W. and GREENE P. (2004) The prevalence of nascent entrepreneurs in the United States: Evidence from the Panel Study of Entrepreneurial Dynamics, Small Business Economics 23(4), 263-284.

REYNOLDS P. D., BOSMA N., AUTIO E., HUNT S., BONO N., DE SERVAIS I., LOPEZ-GARCIA P. and CHIN N. (2005) Global entrepreneurship monitor: data collection design and implementation 1998-2003, Small Business Economics 24(3), 205-231.

REYNOLDS P, STOREY D. J. and WESTHEAD P. (1994) Cross-national comparisons of the variation in new firm formation rates, Regional Studies 28, 443-456.

ROSEN H. S. and WILLEN P. (2002) Risk, return and self-employment. University of Chicago/Princeton University Discussion Paper.

ROSENTHAL S. S. and STRANGE W. C. (2004) Evidence on the nature and sources of agglomeration economies. Handbook of Regional and Urban Economics, Volume 4, 2119-2171

ROTEFOSS B. and KOLVEREID L. (2005) Aspiring, nascent and fledgling entrepreneurs: an investigation of the business start-up process, Entrepreneurship \& Regional Development 17(2), 109-127.

SANTARELLI E., CARREE M. and VERHEUL I. (2009) Unemployment and firm entry and exit: an update on a controversial relationship, Regional Studies 43(8), 1061-1073.

SCHUTJENS V. A. J. M. and WEVER E. (2000) Determinants of new firm success, Papers in Regional Science 79(2), 135-153.

SEGAL G., BORGIA D. and SCHOENFELD J. (2005) The motivation to become an entrepreneur, International Journal of Entrepreneurial Behavior \& Research 11(1), 42-56.

SHEPHERD D.A. (2003) Learning from business failure: propositions about the grief recovery process for the self-employed, Academy of Management Review 28(2), 318-329.

SMALLBONE D. and WELTER F. (2001) The distinctiveness of entrepreneurship in transition economies, Small Business Economies 16(4), 249-262.

SORENSON O. and AUDIA P. G. (2000) The social structure of entrepreneurial activity: Geographic concentration of footwear production in the United States, 1940-1989, American Journal of Sociology 106, 424-462.

SØRENSON J.B. and SORENSON O. (2003) From conception to birth: opportunity perception and resource mobilization in entrepreneurship, in BAUM J. and SORENSON O. (Eds) Geography and Strategy, Advances in Strategic Management 20, pp. 89-117. 
STAM E., THURIK A.R. and VAN DER ZWAN P. (2010) Entrepreneurial exit in real and imagined markets, Industrial and Corporate Change 19(4), 1109-1139.

STUART T. and SORENSON O. (2003) The geography of opportunity: spatial heterogeneity in founding rates and the performance of biotechnology firms, Research Policy 32(2), 229-253.

TAYLOR M. P. (1996) Earnings, independence or unemployment: why become self-employed? Oxford Bulletin of Economics \& Statistics 58(2), 253-266.

TAYLOR M. P. (1999) Survival of the fittest? An analysis of self-employment duration in Britain, Economic Journal 109(454), C140-C155.

THURIK A.R. (2011), From the managed to the entrepreneurial economy: considerations for developing and emerging economies, in NAUDÉ W. (ed.), Entrepreneurship and Economic Development, Houndmills, Basingstoke, England: Palgrave McMillan, 147-165.

THURIK A.R., CARREE M.A, VAN STEL A., AUDRETSCH D.B. (2008), Does self-employment reduce unemployment? Journal of Business Venturing 23(6), 673-686.

TOWNSEND D.M., BUSENITZ L. W., ARTHURS J. D. (2010) To start or not to start: Outcome and ability expectations in the decision to start a new venture, Journal of Business Venturing, 25(2), 192-202.

TUTZ G. (1991) Sequential models in ordinal regression, Computational Statistics \& Data Analysis 11(3), 275295.

UNGER J. M., RAUCH A., FRESE M., ROSENBUSCH N. (2011) Human capital and entrepreneurial success: A meta-analytical review, Journal of Business Venturing 26(3), 341-358.

VAN DER KUIP I. and VERHEUL I. (2004) Early development of entrepreneurial qualities: the role of initial education, Journal of Entrepreneurship Education 2(2), 203-226.

VAN DER SLUIS J., VAN PRAAG M. and VAN WITTELOOSTUIJN A. (2007) Why are the returns to education higher for entrepreneurs than for employees? IZA Discussion Paper No. 3058.

VAN DER SLUIS J., VAN PRAAG M. and VIJVERBERG W. (2005) Entrepreneurship selection and performance: A meta-analysis of the impact of education in developing economies, World Bank Economic Review 19(2), 225-261.

VAN DER ZWAN P., THURIK A. R. and GRILO I. (2010) The entrepreneurial ladder and its determinants, Applied Economics 42(17), 2183-2191.

VAN GELDEREN M., THURIK A. R. and BOSMA N. (2006) Success and risk factors in the pre-startup phase, Small Business Economics 26(4), 319-335. 
VAN GELDEREN M., THURIK A. R and PATEL P. (2011) Encountered problems and outcome status in nascent entrepreneurship, Journal of Small Business Management 49(1), 71-91.

VAN PRAAG C.M. (1996) Determinants of Successful Entrepreneurship. Amsterdam: Thesis Publishers.

VAN PRAAG C.M. (2003) Business survival and success of young small business owners, Small Business Economics 21(1), 1-17.

VAN STEL A. (2005) COMPENDIA: Harmonizing business ownership data across countries and over time, International Entrepreneurship Management Journal 1(1), 105-123.

VAN STEL A. and STUNNENBERG V. (2006) Linking business ownership and perceived administrative complexity, Journal of Small Business and Enterprise Development 13(1), 7-22.

VAN STEL A., STOREY D. and THURIK A. R. (2007) The effect of business regulations on nascent to young business entrepreneurship, Small Business Economics 28(2-3), 171-186.

VAN STEL A. and SUDDLE K. 2008. The impact of new firm formation on regional development in the Netherlands, Small Business Economics 30(1), 31-47.

VERHEUL I., THURIK R., GRILO I. and VAN DER ZWAN P. (2011) Explaining preferences and actual involvement in self-employment: New insights into the role of gender, Journal of Economic Psychology, DOI: 10.1016/j.joep.2011.02.009.

VERHEUL I., WENNEKERS S., AUDRETSCH D. and THURIK A. R. (2002) An eclectic theory of entrepreneurship: Policies, institutions and culture, in AUDRETSCH D.B., THURIK R., VERHEUL I. and WENNEKERS S. (Eds.) Entrepreneurship: Determinants and Policy in a European-US Comparison, Boston/Dordrecht/London: Kluwer Academic Publishers, pp. 11-81.

WATSON J. (2002) Comparing the performance of male- and female-owned businesses: relating outputs to inputs, Entrepreneurship: Theory and Practice 26(3), 91-100.

WENNEKERS S., VAN STEL A., THURIK R. and REYNOLDS P. (2005) Nascent entrepreneurship and the level of economic development, Small Business Economics 24(3), 293-309.

WENNEKERS S., THURIK R., VAN STEL A. and NOORDERHAVEN N. (2007) Uncertainty avoidance and the rate of business ownership across 21 OECD countries, 1976-2004, Journal of Evolutionary Economics $17(2), 133-160$.

WENNEKERS A. R. M., VAN STEL A. J., CARREE M. A. and THURIK A.R. (2010) The relation between entrepreneurship and economic development: is it U-shaped? Foundations and Trends in Entrepreneurship $6(3), 167-237$. 
1

2

3

4

5

6

7

8

9

10

11

12

13

14

15

16

17

18

19

20

21

22

23

24

25

26

27

28

29

30

31

32

33

34

35

36

37

38

39

40

41

42

43

44

45

46

47

48

49

50

51

52

53

54

55

56

57

58

59

60

WESTHEAD P., STOREY D. J. and MARTIN F. (2001) Outcomes reported by students who participated in the 1994 Shell Technology Enterprise Programme, Entrepreneurship \& Regional Development 13(2), 163-185.

WILSON F., KICKUL, J. and MARLINO D. (2007) Gender, entrepreneurial self-efficacy, and entrepreneurial career intentions: Implications for entrepreneurship education, Entrepreneurship Theory and Practice 31(3), 387-406.

ZHAO H., SEIBERT S. E. and LUMPKIN G. T. (2010) The relationship of personality to entrepreneurial intentions and performance: A meta-analytic review, Journal of Management 36(2), 381-404. 
Individual perception administrative complexity

Individual perception insufficient information

Individual perception lack of financial support

Urban

Country's risk tolerance

Country level administrative complexity Country level insufficient information

Country level lack of financial support

Per capita income

Labour productivity growth

Variable description

Male $(=1)$ or female $(=0)$.

Age of the respondent in years.

Age when finished full time education.

To what extent do you agree with the statement: "My school education helped me to develop my sense of initiative (entrepreneurial attitude)"? Dummy variable with 'strongly agree' or 'agree' $=1$ and 'disagree' or 'strongly disagree' $=0$. Dummy variable with value 1 if the mother, father or both are self-employed and value 0 if neither of the parents is self-employed.

To what extent do you agree with the statement: "One should not start a business if there is a risk it might fail"? Value 1 if 'strongly disagree' or 'disagree' is answered and value 0 if 'agree' or 'strongly agree' is answered. Individual values are subtracted from the specific country average.

To what extent do you agree with the statement: "People who started their own business and have failed should be given a second chance"? Value 1 if 'strongly disagree' or 'disagree' is answered and value 0 if 'agree' or 'strongly agree' is answered. Individual values are subtracted from the specific country average. To what extent do you agree with the statement: "It is difficult to start one's own business due to the complex administrative procedures"? Value 1 if "strongly agree' or 'agree' is answered and value 0 if 'disagree' or 'strongly disagree' is answered. Individual values are subtracted from the specific country average. To what extent do you agree with the statement: "It is difficult to obtain sufficient information on how to start a business"? Value 1 if 'strongly agree' or 'agree' is answered and value 0 if 'disagree' or 'strongly disagree' is answered. Individual values are subtracted from the specific country average.

To what extent do you agree with the statement: "It is difficult to start one's own business due to a lack of available financial support"? Value 1 if 'strongly agree' or 'agree' is answered and value 0 if 'disagree' or 'strongly disagree' is answered. Individual values are subtracted from the specific country average. Dummy variable with value 1 if an individual indicates to live in a metropolitan or an urban area and value 0 if this individual lives in a rural area.

Country average of 'Individual risk tolerance'.

Country average of 'Individual perception administrative complexity'.

Country average of 'Individual perception insufficient information'.

Country average of 'Individual perception lack of financial support'.

Gross national income per capita 2006, in purchasing power parity per US\$ (Source: World Development Indicators 2008, World Bank).

Labour productivity growth per person employed in 2006 (source: European Commission; numbers not available for Norway and Iceland). 
Table 2: Values of country-level variables

\begin{tabular}{|c|c|c|c|c|c|c|}
\hline & $\begin{array}{l}\text { Country's } \\
\text { risk tolerance }\end{array}$ & $\begin{array}{c}\text { Country level } \\
\text { administrative } \\
\text { complexity }\end{array}$ & $\begin{array}{c}\text { Country } \\
\text { level } \\
\text { insufficient } \\
\text { information }\end{array}$ & $\begin{array}{c}\text { Country level } \\
\text { lack of } \\
\text { financial } \\
\text { support }\end{array}$ & $\begin{array}{l}\text { Per capita } \\
\text { income }\end{array}$ & $\begin{array}{l}\text { Labour } \\
\text { productivity } \\
\text { growth }\end{array}$ \\
\hline Austria & 0.47 & 0.63 & 0.36 & 0.71 & 36,040 & 1.9 \\
\hline Belgium & 0.41 & 0.78 & 0.56 & 0.78 & 33,860 & 1.9 \\
\hline Cyprus & 0.48 & 0.68 & 0.64 & 0.86 & 25,060 & 2.3 \\
\hline Czech Republic & 0.52 & 0.76 & 0.39 & 0.63 & 22,920 & 4.7 \\
\hline Denmark & 0.67 & 0.77 & 0.34 & 0.66 & 36,190 & 1.3 \\
\hline Estonia & 0.29 & 0.74 & 0.41 & 0.73 & 18,090 & 5.5 \\
\hline Finland & 0.55 & 0.69 & 0.38 & 0.59 & 33,170 & 5.8 \\
\hline France & 0.57 & 0.81 & 0.60 & 0.89 & 32,240 & 1.1 \\
\hline Germany & 0.44 & 0.81 & 0.45 & 0.77 & 32,680 & 2.3 \\
\hline Greece & 0.59 & 0.81 & 0.73 & 0.92 & 30,870 & 2.7 \\
\hline Hungary & 0.35 & 0.76 & 0.57 & 0.90 & 16,970 & 3.0 \\
\hline Iceland & 0.61 & 0.54 & 0.42 & 0.55 & 33,740 & . \\
\hline Ireland & 0.67 & 0.67 & 0.39 & 0.69 & 34,730 & 1.7 \\
\hline Italy & 0.43 & 0.85 & 0.65 & 0.89 & 28,970 & 0.2 \\
\hline Latvia & 0.48 & 0.78 & 0.38 & 0.93 & 14,840 & 7.0 \\
\hline Lithuania & 0.31 & 0.87 & 0.47 & 0.85 & 14,550 & 5.7 \\
\hline Luxembourg & 0.49 & 0.75 & 0.61 & 0.80 & 60,870 & 2.4 \\
\hline Malta & 0.31 & 0.68 & 0.49 & 0.80 & 20,990 & 2.0 \\
\hline Netherlands & 0.57 & 0.73 & 0.25 & 0.61 & 37,940 & 1.8 \\
\hline Norway & 0.67 & 0.75 & 0.39 & 0.64 & 50,070 & . \\
\hline Poland & 0.40 & 0.78 & 0.54 & 0.86 & 14,250 & 2.4 \\
\hline Portugal & 0.28 & 0.84 & 0.78 & 0.91 & 19,960 & 0.5 \\
\hline Slovakia & 0.47 & 0.76 & 0.41 & 0.89 & 17,060 & 4.0 \\
\hline Slovenia & 0.27 & 0.80 & 0.47 & 0.87 & 23,970 & 4.7 \\
\hline Spain & 0.54 & 0.77 & 0.62 & 0.83 & 28,200 & 0.8 \\
\hline Sweden & 0.53 & 0.73 & 0.41 & 0.77 & 34,310 & 4.0 \\
\hline UK & 0.56 & 0.63 & 0.42 & 0.73 & 33,650 & 2.6 \\
\hline US & 0.79 & 0.60 & 0.36 & 0.71 & 44,070 & 1.4 \\
\hline Aggregate & 0.49 & 0.74 & 0.48 & 0.78 & 29,652 & 2.8 \\
\hline
\end{tabular}


Table 3: Correlation matrix of individual-level variables and regional variable ("urban")

\begin{tabular}{|c|c|c|c|c|c|c|c|c|c|c|c|}
\hline & 1 & 2 & 3 & 4 & 5 & 6 & 7 & 8 & 9 & 10 & 11 \\
\hline 1. Gender & 1 & & & & & & & & & & \\
\hline 2. Age & 0.01 & 1 & & & & & & & & & \\
\hline 3. Education level & 0.05 & -0.00 & 1 & & & & & & & & \\
\hline 4. Entrepreneurship education & 0.01 & -0.03 & 0.09 & 1 & & & & & & & \\
\hline 5. Self-employed parents & 0.02 & 0.03 & 0.02 & 0.03 & 1 & & & & & & \\
\hline 6. Indiv. risk tolerance & 0.05 & -0.15 & 0.09 & -0.02 & -0.03 & 1 & & & & & \\
\hline 7. Indiv. stigma of failure & 0.04 & 0.04 & -0.01 & 0.01 & 0.09 & -0.04 & 1 & & & & \\
\hline 8. Indiv. perception admin. complexity & 0.01 & 0.06 & -0.04 & 0.01 & -0.01 & -0.14 & 0.01 & 1 & & & \\
\hline 9. Indiv. perception insufficient information & -0.03 & 0.07 & -0.04 & -0.01 & -0.00 & -0.14 & -0.02 & 0.30 & 1 & & \\
\hline 10. Indiv. perception lack of financial support & -0.03 & 0.01 & -0.04 & 0.03 & -0.04 & -0.13 & -0.06 & 0.31 & 0.23 & 1 & \\
\hline 11. Urban & 0.02 & -0.03 & 0.11 & -0.02 & -0.04 & 0.05 & 0.04 & -0.02 & -0.02 & -0.04 & 1 \\
\hline
\end{tabular}

Spearman correlations are calculated between each pair of binary variables (ranging between -1 and 1). All other values are calculated using Pearson correlation coefficient (also between -1 and 1). The numbers are based on 13,956 observations. 
Table 4: Proportion of engagement levels for each country

\begin{tabular}{|c|c|c|c|c|c|c|c|c|c|}
\hline & $\begin{array}{c}(1) \\
\text { Never } \\
\text { considered }\end{array}$ & $\begin{array}{c}\text { (2) } \\
\text { Thinking }\end{array}$ & $\begin{array}{c}(3) \\
\text { Taking } \\
\text { steps }\end{array}$ & $\begin{array}{c}(4) \\
\text { Young } \\
\text { business }\end{array}$ & $\begin{array}{c}(5) \\
\text { Mature } \\
\text { business }\end{array}$ & $\begin{array}{c}(2 a) \\
\text { Gave up }\end{array}$ & $\begin{array}{l}\quad(5 a) \\
\text { Failure }\end{array}$ & $\begin{array}{c}(5 b) \\
\text { Sell-off }\end{array}$ & $N$ \\
\hline Austria & 0.57 & 0.07 & 0.02 & 0.02 & 0.05 & 0.21 & 0.01 & 0.05 & 475 \\
\hline Belgium & 0.63 & 0.06 & 0.03 & 0.02 & 0.07 & 0.09 & 0.02 & 0.07 & 897 \\
\hline Cyprus & 0.40 & 0.15 & 0.03 & 0.05 & 0.11 & 0.12 & 0.04 & 0.11 & 493 \\
\hline Czech Republic & 0.49 & 0.13 & 0.04 & 0.03 & 0.08 & 0.18 & 0.03 & 0.03 & 910 \\
\hline Denmark & 0.47 & 0.20 & 0.03 & 0.02 & 0.05 & 0.12 & 0.03 & 0.08 & 495 \\
\hline Estonia & 0.59 & 0.09 & 0.06 & 0.04 & 0.08 & 0.09 & 0.03 & 0.03 & 451 \\
\hline Finland & 0.56 & 0.06 & 0.02 & 0.03 & 0.09 & 0.10 & 0.02 & 0.12 & 419 \\
\hline France & 0.57 & 0.10 & 0.03 & 0.02 & 0.04 & 0.17 & 0.01 & 0.07 & 983 \\
\hline Germany & 0.48 & 0.12 & 0.04 & 0.04 & 0.06 & 0.20 & 0.02 & 0.05 & 966 \\
\hline Greece & 0.36 & 0.15 & 0.02 & 0.08 & 0.11 & 0.14 & 0.04 & 0.10 & 989 \\
\hline Hungary & 0.53 & 0.14 & 0.03 & 0.02 & 0.10 & 0.06 & 0.04 & 0.07 & 983 \\
\hline Iceland & 0.41 & 0.14 & 0.05 & 0.04 & 0.14 & 0.09 & 0.02 & 0.12 & 442 \\
\hline Ireland & 0.49 & 0.13 & 0.04 & 0.04 & 0.07 & 0.12 & 0.04 & 0.06 & 477 \\
\hline Italy & 0.56 & 0.07 & 0.04 & 0.03 & 0.05 & 0.15 & 0.02 & 0.08 & 941 \\
\hline Latvia & 0.50 & 0.25 & 0.06 & 0.03 & 0.06 & 0.01 & 0.03 & 0.06 & 451 \\
\hline Lithuania & 0.61 & 0.14 & 0.06 & 0.02 & 0.05 & 0.04 & 0.03 & 0.04 & 471 \\
\hline Luxembourg & 0.55 & 0.08 & 0.03 & 0.03 & 0.04 & 0.20 & 0.02 & 0.06 & 462 \\
\hline Malta & 0.63 & 0.08 & 0.01 & 0.01 & 0.02 & 0.24 & 0.00 & 0.01 & 434 \\
\hline Netherlands & 0.52 & 0.08 & 0.04 & 0.04 & 0.05 & 0.18 & 0.02 & 0.08 & 937 \\
\hline Norway & 0.58 & 0.11 & 0.02 & 0.03 & 0.09 & 0.08 & 0.01 & 0.08 & 461 \\
\hline Poland & 0.45 & 0.14 & 0.06 & 0.02 & 0.08 & 0.15 & 0.04 & 0.06 & 963 \\
\hline Portugal & 0.58 & 0.04 & 0.03 & 0.05 & 0.05 & 0.15 & 0.03 & 0.07 & 969 \\
\hline Slovakia & 0.43 & 0.27 & 0.05 & 0.02 & 0.05 & 0.12 & 0.03 & 0.04 & 479 \\
\hline Slovenia & 0.55 & 0.13 & 0.01 & 0.02 & 0.03 & 0.18 & 0.02 & 0.05 & 492 \\
\hline Spain & 0.57 & 0.08 & 0.03 & 0.03 & 0.06 & 0.14 & 0.03 & 0.06 & 964 \\
\hline Sweden & 0.45 & 0.15 & 0.06 & 0.03 & 0.05 & 0.12 & 0.02 & 0.11 & 478 \\
\hline UK & 0.47 & 0.08 & 0.05 & 0.03 & 0.05 & 0.20 & 0.02 & 0.09 & 971 \\
\hline US & 0.30 & 0.21 & 0.09 & 0.04 & 0.08 & 0.09 & 0.04 & 0.14 & 947 \\
\hline$N$ (proportion) & $\begin{array}{l}9,812 \\
(0.51) \\
\end{array}$ & $\begin{array}{l}2,298 \\
(0.12) \\
\end{array}$ & $\begin{array}{c}770 \\
(0.04) \\
\end{array}$ & $\begin{array}{c}629 \\
(0.03) \\
\end{array}$ & $\begin{array}{l}1,299 \\
(0.07) \\
\end{array}$ & $\begin{array}{l}2,687 \\
(0.14) \\
\end{array}$ & $\begin{array}{c}505 \\
(0.03) \\
\end{array}$ & $\begin{array}{l}1,400 \\
(0.07)\end{array}$ & 19,400 \\
\hline
\end{tabular}


Table 5: Estimation results continuation ratio logit model and four binary logit models (individual-level, regional-level, and country dummies; benchmark country: US)

\begin{tabular}{|c|c|c|c|c|c|}
\hline & $\begin{array}{c}\text { continuation } \\
\text { ratio }\end{array}$ & $\begin{array}{c}\text { Never } \\
\text { considered } \\
\text { vs. higher }\end{array}$ & $\begin{array}{l}\text { Thinking } \\
\text { vs. higher }\end{array}$ & $\begin{array}{l}\text { Taking steps } \\
\text { vs. higher }\end{array}$ & $\begin{array}{c}\text { Young } \\
\text { business vs. } \\
\text { Mature bus. }\end{array}$ \\
\hline Gender & $0.629 * * *$ & $0.776 * * *$ & $0.809 * * *$ & $0.208 * *$ & 0.099 \\
\hline Age & $0.115^{* * *}$ & $0.085^{* * *}$ & $0.187 * * *$ & $0.124 * * *$ & $0.160 * * *$ \\
\hline (Age/100) squared & $-13.461 * * *$ & $-13.574 * * *$ & $-16.461 * * *$ & $-6.436 * *$ & $-11.729 * * *$ \\
\hline Education level & $0.016 * * *$ & $0.033 * * *$ & -0.009 & $-0.020 * *$ & $-0.025 * *$ \\
\hline Entrepreneurship education & $0.213 * * *$ & $0.334 * * *$ & 0.032 & -0.021 & -0.098 \\
\hline Self-employed parents & $0.282 * * *$ & $0.360 * * *$ & $0.344 * * *$ & 0.144 & 0.160 \\
\hline Indiv. risk tolerance & $0.213 * * *$ & $0.316 * * *$ & 0.033 & $0.273 * *$ & -0.041 \\
\hline Indiv. stigma of failure & -0.040 & $-0.156^{* *}$ & -0.015 & 0.183 & 0.332 \\
\hline Indiv. perception admin. complexity & $-0.160 * * *$ & $-0.214 * * *$ & $-0.249 * *$ & -0.149 & 0.084 \\
\hline Indiv. perception insufficient info & -0.044 & -0.051 & 0.042 & -0.019 & 0.030 \\
\hline Indiv. perception lack of fin. support & $-0.076^{*}$ & 0.016 & $-0.190 * *$ & -0.175 & -0.012 \\
\hline Urban & $-0.092 *$ & -0.052 & $-0.136^{*}$ & $-0.261 * *$ & -0.099 \\
\hline Austria & $-0.564 * * *$ & $-1.425 * * *$ & $0.181 * * *$ & $0.584 * * *$ & $0.570 * * *$ \\
\hline Belgium & $-0.596 * * *$ & $-1.655 * * *$ & $0.777 * * *$ & $1.106^{* * *}$ & $0.700 * * *$ \\
\hline Cyprus & $-0.138 * * *$ & $-0.756^{* * *}$ & $0.238 * * *$ & $1.472 * * *$ & 0.046 \\
\hline Czech Republic & 0.026 & $-0.568 * * *$ & $0.567 * * *$ & $1.091 * * *$ & $0.517 * * *$ \\
\hline Denmark & $-0.411 * * *$ & $-0.966 * * *$ & $-0.383 * * *$ & $0.780 * * *$ & $0.253 * * *$ \\
\hline Estonia & $-0.043 * *$ & $-0.688 * * *$ & $1.010 * * *$ & $0.949 * * *$ & $0.499 * * *$ \\
\hline Finland & $-0.405^{* * *}$ & $-1.472 * * *$ & $0.600 * * *$ & $0.841 * * *$ & $0.301 * * *$ \\
\hline France & $-0.763 * * *$ & $-1.648 * * *$ & $0.204 * * *$ & $0.456 * * *$ & 0.086 \\
\hline Germany & $-0.305^{* * *}$ & $-1.106^{* * *}$ & $0.632 * * *$ & $1.040 * * *$ & 0.088 \\
\hline Greece & 0.000 & $-0.653 * * *$ & $0.385 * * *$ & $2.259 * * *$ & $-0.139 *$ \\
\hline Hungary & $0.103 * * *$ & $-0.410 * * *$ & $0.455^{* * *}$ & $1.109 * * *$ & $0.694 * * *$ \\
\hline Iceland & $0.065 * * *$ & $-0.805 * * *$ & $0.688 * * *$ & $1.157 * * *$ & $0.902 * * *$ \\
\hline Ireland & $-0.355^{* * *}$ & $-1.114 * * *$ & $0.191 * * *$ & $1.070 * * *$ & -0.014 \\
\hline Italy & $-0.419 * * *$ & $-1.353 * * *$ & $1.018 * * *$ & $0.703 * * *$ & -0.057 \\
\hline Latvia & $-0.050 * * *$ & $-0.167 * * *$ & $-0.106 * *$ & $0.430 * * *$ & $0.581 * * *$ \\
\hline Lithuania & $-0.409 * * *$ & $-1.056^{* * *}$ & $0.442 * * *$ & $-0.076^{* *}$ & $0.214 * * *$ \\
\hline Luxembourg & $-0.563 * * *$ & $-1.420 * * *$ & $0.196 * * *$ & $0.615 * * *$ & 0.007 \\
\hline Malta & $-1.182 * * *$ & $-1.950 * * *$ & $-1.120 * * *$ & $0.915^{* * *}$ & $1.455 * * *$ \\
\hline Netherlands & $-0.469 * * *$ & $-1.328 * * *$ & $0.697 * * *$ & $0.836^{* * *}$ & $-0.251 * * *$ \\
\hline Norway & $-0.239 * * *$ & $-1.124 * * *$ & $0.449 * * *$ & $1.532 * * *$ & $0.519 * * *$ \\
\hline Poland & $-0.106^{* * *}$ & $-0.641 * * *$ & $0.413 * * *$ & $0.681 * * *$ & $0.770 * * *$ \\
\hline Portugal & $-0.417 * * *$ & $-1.441 * * *$ & $1.691 * * *$ & $1.313 * * *$ & $-0.910 * * *$ \\
\hline Slovakia & $-0.150 * * *$ & $-0.233 * * *$ & $-0.420 * * *$ & 0.092 & $0.173 * * *$ \\
\hline Slovenia & $-0.707 * * *$ & $-1.292 * * *$ & $-0.743 * * *$ & $1.257 * * *$ & $-0.177 * *$ \\
\hline Spain & $-0.556^{* * *}$ & $-1.599 * * *$ & $0.606 * * *$ & $1.225 * * *$ & 0.085 \\
\hline Sweden & $-0.307 * * *$ & $-0.903 * * *$ & $0.181 * * *$ & $0.513 * * *$ & $-0.217 * * *$ \\
\hline United Kingdom & $-0.461 * * *$ & $-1.317 * * *$ & $0.722 * * *$ & $0.479 * * *$ & $-0.273 * * *$ \\
\hline$N$ & 9,823 & 9,823 & 3,863 & 2,155 & 1,523 \\
\hline$R^{2}$ (McFadden) & 0.06 & 0.15 & 0.15 & 0.16 & 0.10 \\
\hline
\end{tabular}

Estimates of thresholds (in case of the continuation ratio logit model) and intercepts (binary logit models) are not shown; If $L L_{m}$ denotes the log-likelihood of the full model and $L L_{0}$ the log-likelihood with thresholds/intercept only, then McFadden's $R^{2}$ equals $1-\left(L L_{m} / L L_{0}\right)$;

Estimates significantly different from zero at the $1 \%(* * *), 5 \%(* *)$, or $10 \%(*)$ level. 
Table 6: Estimation results continuation ratio logit model and four binary logit models (individual-level, regional-level, and country-level)

\begin{tabular}{lccccc}
\hline & $\begin{array}{c}\text { continuation } \\
\text { ratio }\end{array}$ & $\begin{array}{c}\text { Never } \\
\text { considered } \\
\text { vs. higher }\end{array}$ & $\begin{array}{c}\text { Thinking } \\
\text { vs. higher }\end{array}$ & $\begin{array}{c}\text { Taking steps } \\
\text { vs. higher }\end{array}$ & $\begin{array}{c}\text { Young } \\
\text { business vs. } \\
\text { Mature bus. }\end{array}$ \\
\hline Gender & $0.641^{* * *}$ & $0.791^{* * *}$ & $0.789^{* * *}$ & $0.211^{*}$ & 0.094 \\
Age & $0.114^{* * *}$ & $0.083^{* * *}$ & $0.183^{* * *}$ & $0.126^{* * *}$ & $0.156^{* * *}$ \\
(Age/100) squared & $-13.508^{* * *}$ & $-13.438^{* * *}$ & $-16.088^{* * *}$ & $-6.653^{* *}$ & $-11.834^{* * *}$ \\
Education level & $0.017^{* * *}$ & $0.035^{* * *}$ & -0.009 & $-0.026^{* * *}$ & $-0.019^{* * *}$ \\
Entrepreneurship education & $0.217^{* * *}$ & $0.333^{* * *}$ & 0.034 & -0.038 & -0.142 \\
Self-employed parents & $0.285^{* * *}$ & $0.365^{* * *}$ & $0.327^{* * *}$ & 0.196 & 0.162 \\
Indiv. risk tolerance & $0.216^{* * *}$ & $0.330^{* * *}$ & 0.024 & $0.280^{* *}$ & -0.071 \\
Indiv. stigma of failure & -0.052 & $-0.152^{* *}$ & -0.033 & 0.137 & 0.286 \\
Indiv. perception admin. complexity & $-0.167^{* * *}$ & $-0.229^{* * *}$ & $-0.250^{* * *}$ & -0.151 & 0.074 \\
Indiv. perception insufficient info & -0.033 & -0.025 & 0.032 & -0.009 & 0.036 \\
Indiv. perception lack of fin. support & $-0.086^{* *}$ & 0.001 & $-0.170^{*}$ & -0.173 & -0.044 \\
Urban & -0.073 & -0.034 & -0.076 & $-0.288^{* *}$ & -0.086 \\
\hline Country's risk tolerance & $1.795^{* * *}$ & $3.038^{* * *}$ & -0.422 & 0.010 & 0.231 \\
Country level admin. complexity & 0.111 & -0.833 & 1.520 & 0.219 & -0.113 \\
Country level insufficient info & 0.811 & -0.590 & $3.111^{* * *}$ & $4.053^{* * *}$ & -0.831 \\
Country level lack of fin. support & -0.605 & 1.445 & $-4.447^{* * *}$ & $-2.649^{* *}$ & 0.026 \\
Per capita income/1,000 & $-0.049^{*}$ & $-0.100^{* * *}$ & -0.011 & $0.072^{*}$ & -0.049 \\
(Per capita income/1,000) squared & 0.000 & $0.001^{* *}$ & 0.000 & $-0.001^{* *}$ & 0.001 \\
Labour productivity growth & 0.055 & 0.064 & -0.026 & $0.100^{*}$ & 0.037 \\
\hline$N$ & 9,421 & 9,421 & 3,674 & 2,034 & 1,427 \\
\hline
\end{tabular}

Estimates of intercepts are not shown;

Observations of Iceland and Norway are not included in these regressions;

Estimates significantly different from zero at the $1 \%(* * *), 5 \%(* *)$, or $10 \%(*)$ level. 
${ }^{1}$ Note that the concept of competitiveness is surrounded by complexity and elusiveness (KITSON et al., 2004; KRUGMAN, 1991), where some see productivity (growth) as an indicator of competitiveness (PORTER, 1990) and others refer to measures such as (un)employment rates.

${ }^{2}$ There is an ongoing debate about the question of whether or not entrepreneurship can be taught. Some authors suggest that business and management skills can be taught, while creativity and innovation are not "teachable" (JACK and ANDERSON, 1998; MILLER, 1987). Others stress that "entrepreneurial qualities" (e.g., need for autonomy, creativity, risk taking) can be developed in primary and early secondary education (KOURILSKY and WALSTAD, 1998; VAN DER KUIP and VERHEUL, 2004).

${ }^{3}$ There is the risk of a selection effect because students who choose to follow an entrepreneurship major may already be interested in entrepreneurship, or have decided to start a business prior to following an entrepreneurship program (WESTHEAD et al., 2001). In addition, many studies only investigate one school and are not able to generalise the results to other educational institutions.

${ }^{4}$ See ROSENTHAL and STRANGE (2004) for a summary of empirical evidence of the existence of all three of these factors, and for a description of several additional sources of agglomeration effects.

${ }^{5}$ Because country differences are controlled for (by including country dummies), it is believed that the selfperceived location variable is a proper measurement of location density.

${ }^{6}$ Competitiveness is measured as labour productivity growth per person employed. Section 5.4 devotes more attention to this variable.

${ }^{7}$ However, these differences vanish when unregistered firms are included in the analysis (CAPELLERAS et al., 2008). DJANKOV et al. (2002) find that countries with stricter entry regulation are characterised by more corruption and larger unofficial economies.

${ }^{8}$ These interviews were conducted by the Gallup Organization Hungary/Europe January 9-16, 2007. In many countries (including the US) the target sample size amounted to 1,000 respondents. In Austria, Cyprus, Denmark, Estonia, Finland, Iceland, Ireland, Latvia, Lithuania, Luxembourg, Malta, Norway, Slovakia, Slovenia and Sweden the target size was 500. For background information on this data set, see: http://ec.europa.eu/public_opinion/flash/fl_192_en.pdf.

${ }^{9}$ In the original survey, respondents first had to answer "yes" or "no" to the question "Have you ever started a business or are you taking steps to start one?" Subsequently, they had to select either one of the five "yes statements" or one of the three "no statements". As a consequence, entrepreneurs who have "completed" a cycle 
by terminating a given business and are presently thinking about a new one will be classified under the "exentrepreneur" category, rather than under "thinking". For the same reason, those involved in more than one business that may be at different stages of development will only be counted for one of the stages (the respondent choice). In other words, this survey may create a bias in the case of serial or simultaneous entrepreneurs. Despite this possibility the authors believe that such cases are rare based on information from a similar survey, wherein multiple entrepreneurship is recorded, see HESSELS et al. (2011). Therefore, this shortcoming of the survey is unlikely to significantly distort the results.

${ }^{10}$ This three-year period corresponds with the GEM (Global Entrepreneurship Monitor) research program that defines the level of involvement in early-stage entrepreneurial activity as anyone who is either actively engaged in the process of starting a new business or in owning/managing a business that is less than 42 months old. REYNOLDS et al. (2004) explain that this choice of 3.5 years is mainly based on operational, not theoretical, issues, whereas they also notice that the first 4-5 years of a firm are essential for its survival.

${ }^{11}$ Note that for stigma of failure, deviations from the country averages are included as an individual-level factor in our model, but country averages are not included.

${ }^{12}$ Note that the Czech Republic and Slovenia are not performing well either: they occupy positions 9 and 10 with respect to the level of GNI per capita.

${ }^{13}$ Non-reported investigation of moderation effects by means of interaction terms between all individual-level variables and gender reveals that there are three coefficients with significant differential impacts on female and male entrepreneurial progress in the "overall" model: self-employed parents, risk tolerance, and perception of lack of financial support. Results can be obtained from the authors upon request. See also VERHEUL et al. (2011) for a discussion of gender and moderation effects.

${ }^{14}$ For the binary dependent variables, a random intercept logistic regression is used. This two-level model is similar to the regular binary logit model with an additional country-specific random intercept. That is, each country has its own intercept that depends on the country-specific variables in Table 1, an intercept, and an error term that captures country-specific influences that are not included in the model. Thus, observed and unobserved heterogeneity across countries is controlled for. For estimation of the random-intercept logit model, numerical approximation of integrals is needed. The Stata command xtlogit is used with adaptive Gauss-Hermite quadrature and 50 quadrature points.

For the continuation ratio logit regression (first column in Table 6) a simpler, but similar, approach is used. The estimated coefficients of the country dummies in Table 5 (but then excluding observations from Iceland and 
Norway) are regressed on the country-specific variables in Table 1 to obtain the coefficients of the country-level variables. A drawback of this simplified approach is that the coefficients of the country dummies are treated as given, whereas actually they are included in a certain confidence interval.

${ }^{15}$ Extending the set of country-level variables with stigma of failure does not lead to different results, as this variable does not have a significant impact across all regressions. In addition, replacing risk tolerance with stigma of failure leads to insignificant results for stigma of failure. In both situations, the significances of the other country-level variables only marginally change.

${ }^{16}$ Note that, given the data set, it is not possible to test for the direction of causality in this relationship. It could be that labour productivity growth results from start-up and young business activity, rather than vice-versa.

${ }^{17}$ The country-level risk tolerance variable results from the country average of the agreement with the statement "One should not start a business if there is a risk it might fail". 